\title{
Dynamics and Economic Aspects of Climate Change
}

\author{
A chapter for the book Combating Climate Change: An Agricul- \\ tural Perspective, edited by Manjit S. Kang \& Surinder S. Banga, \\ to be published by CRC Press, 2013
}

\author{
José A. Tapia Granados ${ }^{1}$ and Óscar Carpintero²
}

\begin{abstract}
Climate change is the alteration of climate directly or indirectly caused by human activities that modify the composition of the atmosphere. Greenhouse gases (GHG), particularly $\mathrm{CO}_{2}$, are accumulating in the atmosphere, with the consequent warming. Global mean temperature has risen since preindustrial times, with most of the warming occurring in the last three decades. The consequence are increasingly frequent extreme weather events.

Though economists have often disagreed about economic aspects of global warming, views as those of the Stern Review-that purports global warming as a major economic problem implying risks of disaster and demanding the use of major resources- are increasingly common. The idea that with development and technological progress total GHG emissions or at least emissions per capita would decrease has been discredited by evidence of a link between increased economic activity and greater emissions. In general, global emissions of $\mathrm{CO}_{2}$ have increased at rates correlated with the annual increase of world GDP (WGDP). Furthermore, the annual increase in atmospheric concentrations of $\mathrm{CO}_{2}$ is correlated with the growth of WGDP.

Impacts of climate change and strategies to mitigate them have been often subjected to integrated assessment models (IAMs), which involve many controversial aspects. For global warming above 2 or $3{ }^{\circ} \mathrm{C}$ IAMs agree that there will be a reduction of long-term social well-being and a negative impact suffered mostly by low-income regions, but different IAMs strongly disagree on the level of human-induced damage, with estimates ranging from less than $1 \%$ to over $10 \%$ of WGDP. However, significant economic and technological potentials for mitigation and emissions reductions are now available. These would be larger if non-technical options (changes in consumption models and lifestyles) are also considered.

Direct emissions of GHG related to agriculture are mainly emissions of $\mathrm{CH}_{4}$ and $\mathrm{NO}_{2}$. Indirect emissions of GHG from agriculture include large $\mathrm{CO}_{2}$ emissions from land use change, when natural ecosystems are transformed into cultivated land. The sum of direct and indirect emissions may represent annually $1 / 4$ of GHG global emissions, with about $3 / 4$ of GHG agricultural emissions coming from low-income countries. Global warming impacts on agriculture include decreased yields in warmer environments, increased yields in colder ones due to longer growing season and $\mathrm{CO}_{2}$ fertilization (that perhaps could be offset by ozone emissions), more insect outbreaks and risk of wildfires, crop damage, and land and water degradation. Mitigation measures focused in soil carbon sequestration by modifying practices of intensive agriculture and moving towards agroecology or low-carbon agriculture are needed.

Permits trading and the implementation of a carbon tax are the major options in the public debate about policies to mitigate climate change by reducing emissions. The European Trading Scheme (ETS) implemented in 2005 has yielded very poor results, failing to reduce emissions and with the emissions market presently inactive, with a price of emissions at almost zero. A carbon tax would reduce emissions by discouraging consumption of "carbon-rich" commodities and therefore promoting recycling, reusing and innovation toward production and consumption of "carbon-poor" commodities, but there have been only some timid steps to implement such a tax in some countries, and there is strong opposition to it
\end{abstract}

\section{Introduction}

The United Nations Framework Convention on Climate Change (UNFCCC) defines climate change as "a change of climate which is attributed directly or indirectly to human activity that alters the composition of the global atmosphere and which is in addition to natural climate variability observed over comparable time periods." Using this definition of climate change, a joint statement of several science academies stated that in spite of uncertainties about something as complex as world's climate, there is now strong evidence that significant global warming is occurring (National Academies, 2005). The scientific consensus-backed by the Intergovernmental Panel on Climate Change (IPCC), the World Meteorological Organization, and a variety of scientific organizations and national academies-is that the process of global warming is attributed to anthropogenic influence, i.e., to gases emitted to the atmosphere because of industrial, agricultural, transport and other types of human activity (National Academies, 2005). The so-called greenhouse gases (GHGs) increase the

\footnotetext{
${ }^{1}$ Institute for Social Research (SEH/SRC), University of Michigan, Ann Arbor, USA (jatapia@umich.edu).
}

${ }^{2}$ Department of Applied Economics, University of Valladolid, Valladolid, Spain (carpin@eco.uva.es). 
capture of solar radiation by allowing less infrared radiation from the sun to be deflected back to the outer space. Climate change is related to a number of GHGs, including halocarbons, nitrous oxide $\left(\mathrm{N}_{2} \mathrm{O}\right)$, methane $\left(\mathrm{CH}_{4}\right)$, and carbon dioxide $\left(\mathrm{CO}_{2}\right)$, but the consensus in the geosciences community is that $\mathrm{CO}_{2}$ is the most important GHG, and as such increasing atmospheric levels of $\mathrm{CO}_{2}$ represent the key factor to understand and explain global warming (Solomon et al., 2007).

Deforestation and other changes in the uses of soil are important determinants of climate change, because they modify the degree to which vegetation growth captures $\mathrm{CO}_{2}$. In fact, the monthly mean concentrations of atmospheric $\mathrm{CO}_{2}$ measured on the Hawaiian volcano Mauna Loa since March 1958 (the so-called Keeling curve) reveal a rising trend across quite a regular oscillating seasonal pattern (Figure 1), which is caused by differences in the ability of photosynthesis and respiration of the terrestrial biosphere and other sinks of $\mathrm{CO}_{2}$ to absorb the gas through the annual seasonal cycle (Conway et al., 1994). Atmospheric concentrations of $\mathrm{CO}_{2}$, now approaching levels of $400 \mathrm{mg} \mathrm{kg}^{-1}$ (or parts per million, ppm), were at levels below $300 \mathrm{mg} \mathrm{kg}^{-1}$ in preindustrial times.

As a consequence of the greenhouse effect, global mean temperatures have increased 7 or 8 tenths of $1^{\circ} \mathrm{C}$ since 1900, with most of this increase occurring in the last three decades (Smith, 2008; Menne et al., 2009). This increase of less than $1^{\circ} \mathrm{C}$ in mean annual global temperature seems small compared with natural variability. However, this apparently small shift in the mean temperature is associated with more frequent extreme weather events, such as heat waves, droughts, tornados, heavy rains, and storms. Taking as reference the period 1950-1980, during the past several years the portion of global land where summer temperatures have been more than three standard deviations $(3 \sigma)$ above the mean, has averaged $10 \%$, when it should have been only $0.1 \%$ or $0.2 \%$ if the climatology of 1950-1980 had still prevailed (Hansen et al., 2012a). Examples of temperature anomalies exceeding $3 \sigma$ are the heat waves and droughts that in 2010 covered much of the Middle East, Western Asia and Eastern Europe, and in 2011 Oklahoma, Texas and Mexico. Analyzing the variability of global temperatures since 1911, Rahmstorf and Coumou (2011) concluded that "given the strong evidence that most of the warming of the past 50 years is anthropogenic, most of the recent extremes in monthly or annual temperature data would probably not have occurred without human influence on climate." The rapid loss of mass of the Greenland and Antarctic ice sheets in recent years (Velicogna, 2009, Rignot et al., 2011) is also evidence of atmospheric and ocean warming.

Assuming the continuation of the observed patterns of warming and the causes that produce them, the increase in global temperature will accelerate the retreat of glaciers and sea ice, and the changes in patterns of precipitation. An expansion of subtropical deserts, the extinction of large number of species and, eventually, a significant rise in ocean levels are to be expected (Lu et al., 2007). Changes in crop yields are also part of the process of climate change. Considering potential interactions, an increase of global temperature of $4{ }^{\circ} \mathrm{C}$ above preindustrial levels would imply that the limits for human adaptation will be exceeded in many regions, while the limits of adaptation for natural systems would largely be exceeded throughout the world and the ecosystem services upon which human livelihoods depend would not be preserved (Warren, 2011).

This chapter discusses climate change focusing on economic factors and implications, and more concretely, the relation between economic growth and global warming that can be inferred from the available data.

\section{Economics and climate change}

Economists have been quite divided on their views on climate change since global warming became an issue of social and political debate in the 1980s. Many economists agreed with views that minimized the importance of global warming or rejected proposed policies to prevent or reduce climate change for not being cost-efficient. In the last two decades, there have been strong disagreements among economists on the relation between economic growth and $\mathrm{CO}_{2}$ emissions, on the implications of global warming for human welfare and on the policies to prevent climate change (Holtz- 
Eakin and Selden, 1995; Spash, 2002; McCormick, 2004; Stern, 2006; Nordhaus, 2008; Krugman, 2011).

In 2004, as part of the so-called Copenhagen Consensus, a panel of well-known economists, including five recipients of the Nobel Memorial Prize in Economic Sciences concluded that policies that had been proposed to prevent global warming-for instance, in the Kyoto protocol-had "costs that were likely to exceed the benefits." The panel agreed that global warming was an issue to be addressed-though much less important than other problems-and concluded that approaches based on "too abrupt a shift toward lower emissions of carbon" would be needlessly expensive (Lomborg, 2004). Continuing with a position that played down the importance of global warming, the panel of leading economists-slightly changed-in the Copenhagen Consensus 2008 and 2009 argued for research on technological fixes for global warming. Investigation on low-carbon energy technologies was, however, ranked 14th among research priorities, after research on malaria and on acute management of heart attacks (Copenhagen Consensus, 2012). These views of the Copenhagen Consensus contrast not only with those of many natural scientists but also with the position of other well-known economists who have referred to climate change as a major problem to be tackled with urgency and by investing major resources (Adam, 2009; Krugman, 2011; Stern, 2011).

A common hypothesis in economic theorizing on global warming has been that the relation between economic growth, air pollutants in general, and $\mathrm{CO}_{2}$ in particular, has the shape of an inverted U, the EKC or environmental Kuznets curve (Nakicenovic, 1996; Schmalensee et al., 1998; Sun and Meristo, 1999). If $\mathrm{CO}_{2}$ emissions followed an $\mathrm{EKC}$, they would first increase and then decrease with the growth of the gross domestic product (GDP). However, other economists could not find any evidence in favor of the EKC for $\mathrm{CO}_{2}$. Thus the hypothesis has been disputed on both theoretical and empirical grounds (Ekins, 1997; de Bruyn et al., 1998; Stern and Common, 2001; Stern, 2004; Dijkgraaf and Vollebergh, 2005; Müller-Fürstenberger and Wagner, 2007; Wagner, 2008).

Estimates of $\mathrm{CO}_{2}$ global emissions growing at increasingly faster annual rates since the $1980 \mathrm{~s}$ (Raupach et al., 2007; Le Quéré et al., 2009) are quite inconsistent with an $\mathrm{EKC}$ for $\mathrm{CO}_{2}$. In fact, the growth of emissions since 2000 has been greater than for the most fossil-fuel-intensive emissions scenarios developed in the late 1990 s by the IPCC. At both the national and the global level, evidence is mounting on the link between increased production of goods and services and growth of GHG emissions, $\mathrm{CO}_{2}$ in particular (Roca and Alcántara, 2001; Quadrelli and Peterson, 2007; Raupach et al., 2007; Tol et al., 2009). With evidence in favor of an EKC for $\mathrm{CO}_{2}$ largely disputed and with emissions increasing in recent years, the emerging consensus seems to be that the curve is shaped as an N rather than as an inverted U (de Bruyn et al., 1998; Dinda et al., 2004; MartinezZarzoso and Bengochea-Morancho, 2004). Almost without exception economic activity involves energy inputs and $\mathrm{CO}_{2}$-generating combustion is the primary source of energy in the modern world. For this reason, the hypotheses that the global intensity of economic activity is strongly correlated (i) with the volume of annual $\mathrm{CO}_{2}$ emissions, and (ii) with the rate of annual increase in $\mathrm{CO}_{2}$ atmospheric concentrations, seem both plausible. There is evidence supporting both.

\subsection{Economic growth and $\mathrm{CO}_{2}$ emissions}

Both total and per capita $\mathrm{CO}_{2}$ emissions have generally been growing in all countries during the $2 \mathrm{O}^{\text {th }}$ century (Raupach et al., 2007), but across the long-term growth of emissions, there have been many short-term fluctuations. Since the prevention of global warming centres around policies to reduce $\mathrm{CO}_{2}$ emissions, it seems interesting to ascertain in what countries and in what periods emissions decreased during the years for which emission estimates are available. For that purpose, starting with the 48 nations that had population over 20 million at the end of the $20^{\text {th }}$ century, and smoothing the curves of total emissions with a 5-year centered moving average, we computed the mean annual rate of trend growth for each quinquennium of the period 1950-1999. Considering these rates, the countries in which emissions decreased were the following (in parenthesis is the rate of decline of emissions during the 5 -year period): 
- in 1950-1954, none; in 1955-1959, Morocco (o.9), Venezuela (o.7), and Zaire (3.4);

- in 1960-1964, China (4.7), and Zaire (1.7); in 1965-1969, Egypt (1.6);

- in 1970-1974, Ethiopia (3.4), Uganda (3.6), United Kingdom (0.7), and Venezuela (o.6); in 19751979, West Germany (0.3), France (0.2), Iran (0.9), Sudan (4.2), Uganda (8.4), United Kingdom (0.7), Tanzania (3.4), and Viet Nam (2.2);

- in 1980-1984, Argentina (0.1), Canada (1.0), West Germany (1.7), France (3.9), Italy (o.7), Japan (0.3), Kenya (4.1), Peru (1.4), Philippines (2.3), Spain (1.2), United Kingdom (1.2), and United States (0.7); in 1985-1989, Afghanistan (3.9), West Germany (0.2), France (0.6), Myanmar (4.5), Nigeria (3.8), Poland (2.9), Romania (3.0), Tanzania (0.1), Viet Nam (0.2), and Yugoslavia (0.3);

- in 1990-1994, Afghanistan (9.7), France (0.6), Nigeria (3.7), Poland (1.6), Romania (5.9), Sudan (2.4), United Kingdom (1.3), Zaire (6.0); in 1995-1999 Afghanistan (6.3), China (0.5), Colombia (1.5), North Korea (14.2), Germany (0.8), Poland (2.4), Romania (4.7), Russian Federation (1.7), Saudi Arabia (1.7), Ukraine (5.2), and Tanzania (0.6).

The pattern is very suggestive of decreasing $\mathrm{CO}_{2}$ emissions during periods of weak economic growth and of rising $\mathrm{CO}_{2}$ emissions during expansions. There were very few countries in which emissions declined in the 1950s-1960s; one was China where emissions declined in 1960-1964. All this is highly consistent with the fact that in the $1950 \mathrm{~s}-1960 \mathrm{~s}$ the world economy grew at very fast rates (Maddison, 2001); and in China the early 1960s were a period of strenuous economic restructuring after an extreme disruption of the economy in 1960, during the so-called Great Leap Forward (Zhang and Fan, 2003). Things changed in the 1970 s when emissions started to fall in many more countries, including high income countries, such as the United Kingdom, where emissions declined in 1970-1974, in 1975-1979, in 1980-1984 and again in 1990-1994. In each of the quinquennia of the 1980 s and 1990s, about a dozen countries had negative growth of emissions. While in the 1950s1960s, emissions decreased in just a handful of low-income economies, in the 1980s emissions decreased in the USA, West Germany, the United Kingdom, Canada and other high-income countries. This occurred probably as a consequence of the declines in economic activity that occurred during this decade, the policies of energy saving and efficiency implemented as a response to rising petroleum prices and the oil-embargo triggered by the Yom-Kippur war, and the deindustrialization processes at work in high-income countries, such as the United Kingdom and others. During the late 1980s, in Eastern Europe and the nations formerly part of the USSR, sudden political changes ushered in a period of economic transition from central planning to liberalized markets, and in the 1990s, there were major disruptions of economic activity with skyrocketing unemployment and significant increases in poverty and adult mortality (Stillman, 2006). At the same time, $\mathrm{CO}_{2}$ emissions greatly declined. For instance, in Romania, emissions dropped $>5 \%$ per year throughout the 1990s; and in Ukraine $5.2 \%$ per year in the late 1990s. In comparison, in the early 1980 , $\mathrm{CO}_{2}$ emissions had dropped a little over 1\% per year in the United Kingdom and a little below 1\% in the USA.

We also determined the years and countries, among the nations with population more than 20 million in 2000, in which the annual growth of emissions, total or per capita, was high or low since the 1920 s to the present. With very few exceptions, total emissions decreased in the early 1930 s (results not shown), the time of the Great Depression that affected most market economies worldwide. Contrarily, strong and sustained annual increases $->4 \%-$ in total emissions are particularly concentrated in the 1920s, and the 1950s-1960s. In the 1950s-1960s, there were also large increases in per capita emissions. In many countries, both total and per capita emissions increased $>4 \%$ per year in the most recent decades.

Considering the U.S. economy, its annual rate of growth and the rate of increase of U.S. emissions of $\mathrm{CO}_{2}$ follow each other quite closely. Emissions dropped strongly in the recession of the early 1920s, but they dropped much more lastingly and deeply during the Great Depression in the early 1930s, and again in the recessions of 1938, 1949, the mid-1970s, and the early-1980s. The correlation of the rate of growth of emissions with the rate of growth of real GDP (both are stationary 
series, no spurious correlation is involved $)$ is $0.53(P<0.0001)$ for the 1801-2002 period and is also strongly positive for all the sub-periods of these two centuries. Examining the correlation between year-to-year rates of growth of GDP and emissions during the four consecutive half-centuries between 1800 and 2000 (Table 1), it seems that the link between economic growth and growth of $\mathrm{CO}_{2}$ emissions strengthened with the passage of time, because the correlation went up in each consecutive 50-year period, from $0.37(P<0.01)$ in the first half of the $19^{\text {th }}$ century to 0.74 $(P<0.0001)$ in 1950-1999. These correlations indicate that $\mathrm{CO}_{2}$ emissions are what economists refer to as a procyclical variable, that is, a variable that moves in parallel with the business cycle, rising in periods of economic upturn and declining in periods of economic downturn.

In high-income countries, such as the United Kingdom, France, or Germany, the plots of per capita emissions versus per capita GDP (Figure 2) seem to suggest a delinking of GDP growth and growth in emissions, because in the most recent decades, per capita emissions declined with rising per capita GDP. These cases seem consistent with an EKC as an inverted $\mathrm{U}$ for $\mathrm{CO}_{2}$. A possible explanation might be that a high level of development creates conditions for the decarbonization of the economy, by making both production and consumption uses of energy much more efficient. We believe that a much more likely explanation is, however, that in these countries, the industrial base was displaced by a service economy at the same time that nuclear energy became a major source of energy. 3 But, regrettably, it is very unlikely that energy use and $\mathrm{CO}_{2}$ emissions implied by national consumption have actually been reduced in these countries. With globalisation and increased international trade the energy consumption and $\mathrm{CO}_{2}$ emissions associated with consumption in these countries have been displaced to the rest of the world, from which goods are then imported to a "clean" economy (Suri and Chapman, 1998; Taskin and Zaim, 2000; Le Quéré et al., 2009). Indeed, in countries, such as Australia, Canada, and the USA, increasing levels of emissions per capita are observed with increasing levels of GDP per capita (Figure 2), suggesting an $N$-shaped, rather than a U-inverted curve. In-high income countries, such as Italy or Japan, where the industrial sector was still a major component of the economy in the late $20^{\text {th }}$ century, it seems that international trade was not able to push the relation between economic growth and $\mathrm{CO}_{2}$ emissions downward to the right side of the $\mathrm{EKC}$, and the connection between economy and emissions strengthened (Figure 2).

Global emissions of $\mathrm{CO}_{2}$ have increased at rates strongly correlated with the absolute growth of the global economy (Figure 3), as measured by the annual increase of "world GDP" (WGDP). Indeed, a major drop in the growth of estimated emissions occurred in 2009 as a consequence of the "Great Recession" that affected the global economy. However, even in 2009 when the global economy contracted $2.25 \%$, global emissions did not decrease, they just ceased growing to start growing again next year when the world economy somewhat recovered. This shows how dependent on fossil fuels the world economy has become in recent years. In earlier recessions of the global economy-in the mid-1970, early-1980s, early-1990s and late-1990s-emissions not only decreased in many countries, as we have shown, but also worldwide (Figure 3).

The notion that economic growth will reduce the carbon intensity of the world economy (the ratio of global emissions to WGDP) is inconsistent with the fact that the carbon intensity of the global economy has increased in recent years. In 2010, after the Great Recession, WGDP grew 5.0\%, but emissions grew faster, $5.9 \%$. Furthermore, the average growth of global $\mathrm{CO}_{2}$ emissions was $3.1 \%$ per year in 2000-2011, while it had been 1.0\% per year in 1990-2000, and $2.0 \%$ per year in $1980-$ 1990 (Peters et al., 2012).

In summary, what the historical evidence indicates is that drops in total emissions occur when there is a contraction of the economy, as happened in the West in the 1930s and the 1980s, in the East in the 1990s, and in the global economy in 2009. Similarly, in periods of accelerated global

\footnotetext{
${ }^{3}$ In France the nuclear power share of electricity generation grew from 25\% to 77\% between 1980 and 2000; in United Kingdom it increased from $12 \%$ to $23 \%$; in Germany, from $26 \%$ to $38 \%$. Consequences of this energy strategy are the risks of industrial disaster associated with nuclear power (sadly illustrated recently by the disaster of Fukushima, Japan, in 2011) and the production of substantial quantities of radioactive waste.
} 
economic growth, e.g., the 1950 , the 1960 s, or the early years of the $21^{\text {st }}$ century, emissions greatly increased. Neither in total emissions nor per capita $\mathrm{CO}_{2}$ emissions does the historical experience suggest that emissions stabilize or drop after some level of income per capita is reached.

\subsection{Economic growth and $\mathrm{CO}_{2}$ atmospheric levels}

Estimates of $\mathrm{CO}_{2}$ emissions are usually accepted in the research community and therefore it is to be assumed that they are considered more or less reliable. Emissions are computed from economic data on consumption, exports and imports of fossil fuels, and cement production. Because these data are also inputs to compute GDP estimates, correlations between both kinds of estimates could subject to similar estimation errors. Contrarily, $\mathrm{CO}_{2}$ atmospheric concentrations are not estimated but measured with high reliability. Therefore, a correlation of the rate of increase of atmospheric $\mathrm{CO}_{2}$ and the rate of growth of the global economy is stronger evidence that the world economy is linked with the build-up of the greenhouse effect and, therefore, with the process of global warming.

Proving a short-term link between WGDP growth and the increase in atmospheric $\mathrm{CO}_{2}$ is complicated by the fact that at an annual timeframe, $\mathrm{CO}_{2}$ concentrations are subject to the influence of two natural phenomena, volcanic activity and the quasi-periodic climatic pattern called El Niño Southern oscillation (ENSO). However, multivariate analysis of the influence of the world economy, volcanic activity and ENSO activity on $\mathrm{CO}_{2}$ levels allows us to show that the annual increase in atmospheric $\mathrm{CO}_{2}$ is significantly linked to the growth of the global economy (Tapia Granados et al., 2012). Years of above-trend WGDP are years of greater rise in $\mathrm{CO}_{2}$ concentrations, and similarly, years of below-trend WGDP are years of smaller rise in $\mathrm{CO}_{2}$ concentrations.

A link between (a) the volume of global economic activity, measured roughly by national GDPs that add up to WGDP, (b) worldwide emissions of $\mathrm{CO}_{2}$, and, consequently, (c) atmospheric levels of $\mathrm{CO}_{2}$ would be based on the known fact that most activities generating added value to WGDP also imply combustions (Chandr Jaunky, 2011). It is true that in many countries a sizable fraction of GDP corresponds to the services sector that by itself generate less emission of $\mathrm{CO}_{2}$ than manufacturing. However, these service activities often involve the consumption of imported goods, which implies emissions in manufacturing in the exporting countries, and transportation-a major source of $\mathrm{CO}_{2}$. The increasing share of the services sector in GDP, the relocation of manufacturing to other countries, and the efficiency of reduced use of energy for concrete industrial or domestic activities may weaken the link between rising GDP and increasing $\mathrm{CO}_{2}$ emissions at the national level. However, increasing worldwide manufacturing, transport of raw materials, merchandise and people, and domestic use of energy will strengthen the link between global emissions and WGDP. Indeed, two thirds of the increase in the growth of $\mathrm{CO}_{2}$ concentrations during 2000-2007 has been attributed to increasing global economic activity (Canadell et al., 2007), and the physicochemical intensity of WGDP, measured either in estimated energy consumption per dollar, or in $\mathrm{CO}_{2}$ estimated emissions per dollar, increased during 2000-2005, reversing a decline before 2000 (Pielke et al., 2008). The conclusion is that "prosperity"-represented by greater levels of growth of national economies or the global economy-represents an escalation of the main cause of climate change.

\section{Monetary Valuation of Climate Change: Integrated Assessment Models}

Once the relation between economic growth and $\mathrm{CO}_{2}$ emissions and concentrations is understood, and the threats posed by climate change are realized, there are four possible options for society: (i) to do nothing and continue in the 'business-as-usual scenario'; (ii) to adapt to the consequences of climate change; (iii) to reduce the emissions to curb the problem at its source; and (iv) to offset emissions-or rising temperatures-by increasing the absorptive capacity of $\mathrm{CO}_{2}$ sinks or other technical measures. In the climate change literature, the second strategy is commonly referred to as adaptation, the third as mitigation, and the fourth as geoengineering, or climate engineering.

We will discuss in this section the economic aspects of adaptation and mitigation strategies. Geoengineering for managing climate change, for instance, aiming to remove $\mathrm{CO}_{2}$ directly from the 
air-e.g., through ocean fertilization-or to block sunlight to reduce atmospheric warming-has been mentioned in the economic literature (Barrett, 2008) and has been supported by celebrities (Vidal, 2012). According to the IPCC (2007a, p. 621), little is known about effectiveness, costs or potential side-effects of such unconventional options. We believe geoengineering for managing climate change poses major ethical and scientific problems and we will not discuss it here.

\subsection{Results of Integrated Assessment Models}

Strategies to mitigate climate change involve different types of costs and benefits (economic, social, and environmental). Some of them can be easily expressed in monetary terms. In other cases, however, monetization is very difficult. For more than two decades, economists have contributed proposal and analyses of these strategies. The objective would be to estimate in monetary terms the impacts associated with climate change, and assess the benefits and costs associated with different options to reduce emissions of GHG.

Because climate change is a multidimensional problem, it requires simultaneous consideration of multiple scientific fields. Thus, since the 1990s, integrated assessment models have been developed, combining information from different social and natural sciences to understand the interactions between two complex systems: climate and society (Weyant et al., 1996; Pearce et al. 1996; Tol, 2000, 2009; Goodess et al., 2003; Courtois, 2004) As defined by the IPCC, an integrated assessment model (IAM) is a convenient framework "for combining knowledge from a wide range of disciplines in order to conduct coordinated exploration of possible future trajectories of human and natural systems, development of insights into key questions of policy formation, and prioritisation of research needs in order to enhance our ability to identify robust policy options" (IPCC, 1996). In the so-called macroeconomics-oriented IAMs, the main focus is on economic impacts and the two main tools for assessment are cost-benefit analysis and cost-effectiveness analysis. In the costbenefit analysis, the costs of climate change and the costs of control measures or mitigation are measured in the same monetary units and compared with the benefits of adopting these measures (i.e., environmental damage avoided). The purpose is to calculate the option that maximizes net benefits (the difference between benefits and costs). In cost-effectiveness analysis, a target is set (e.g., to reduce emissions, or to reach stability of atmospheric $\mathrm{CO}_{2}$ at a certain level) and the best control or mitigation option is selected by choosing the one with the lowest cost. In general, damages caused by climate change are defined as the difference in "social welfare" between a scenario with anthropogenic climate change and one without it. The variation of "social welfare" as a consequence of the costs of climate change and the adoption of control and mitigation policies is usually measured as a percentage of GDP. Finally, it should be noted that macroeconomics-oriented IAMs rely on the optimization and equilibrium approach of neoclassical economics: welfare optimizing identical agents, the economy operating in equilibrium in competitive markets, with perfect information, etc. 4 When considering the world at large, the global IAM aggregates the macroeconomic and environmental variables of different countries into a single output, capital stock, technology, and emissions.

A review of IAMs developed during the last two decades reveals two IAM generations. The first generation of IAMs developed in the 1980 s and early 1990 (see reviews in Pearce et al., 1996; Tol et al., 2000) assessed the effects of a doubling of atmospheric levels of $\mathrm{CO}_{2}$ from pre-industrial times with a consequent rise of $2.5^{\circ} \mathrm{C}$ in temperature (Nordhaus , 1991; Ayres and Walters, 1991; Cline, 1992; Titus, 1992; Fankhauser, 1995; Tol, 1995). In general, as illustrated in Table 2, this increase in temperature leads, in these models, to monetary costs ranging between $1 \%$ and $2 \%$ of WGDP, but with significant regional differences, because losses in developed countries would be between $1 \%$ and $1.5 \%$ of GDP, whereas in developing countries they would be between $2 \%$ and $9 \%$ of GDP. Thus,

\footnotetext{
${ }^{4}$ Neoclassical economics is the predominant theoretical approach in economics, but many economists do not subscribe its main tenets and feel closer to other schools (Austrian, institutionalist, Keynesian, post-Keynesian, Marxian, ecological, etc.) of economics.
} 
according to these models, while developing countries, which are the least contributors to climate change, suffer the highest costs of global warming, wealthy countries, with greater responsibility for GHG emissions, show "better" results.

The IAMs of the first generation differ in the assumptions, categories of damage, and monetized impacts that were considered. For instance, while Nordhaus (1991) considered the impacts of climate change on activities such as agriculture, or energy production, or the rise in sea level, in other IAMs (Cline, 1992; Titus, 1992; Fankhauser, 1995; Tol, 1995), monetary estimates of nonmarket human or environmental costs (human morbidity and mortality, air and water pollution, etc.) were included. In general, the assumption of a fixed increase in temperature $\left(2.5{ }^{\circ} \mathrm{C}\right)$ was a major limitation of the first generation IAMs, which therefore could not provide an assessment of the impacts of progressive increases in global temperature. The second generation IAMs (Mendelsohn et al., 1998, Nordhaus and Boyer, 2000; Tol, 2002; Stern, 2006) attempted to overcome this shortcoming. They, however, produced large inconsistencies in the impact estimates. For example, Mendelsohn et al. (1998) estimated the monetary value of the impact of climate change on five markets (agriculture, energy, forestry, water and coastal zones). This IAM, as the one authored by Tol (2002), predicted inequality of impacts between regions, concluding that an increase in global temperature between 1.2 and $3.5{ }^{\circ} \mathrm{C}$ taking place until 2100 would have a very slightly beneficial overall aggregate impact, increasing WGDP by some $0.2 \%$. Contrarily, in the IAM by Nordhaus and Boyer (2000) estimated costs were between $1.5 \%$ and $2 \%$ of WGDP under the assumption of a doubling of $\mathrm{CO}_{2}$ levels with an increase of global temperatures of $2.5{ }^{\circ} \mathrm{C}$ in 2100 . This IAM by Nordhaus and Boyer (2000) considered market and non-market impacts-in agriculture, other markets, sea-level rise, health, amenities, human settlements, and agricultural ecosystems-and was the first to provide cost estimates of the risk of catastrophe. Under the assumption of a temperature increase of $6{ }^{\circ} \mathrm{C}$, implying catastrophic harm, the costs estimated by Nordhaus and Boyer rose to $7 \%$ of WGDP.

Despite differences in the impact categories covered, periods and scenarios considered, the results of different IAMs can be summarized as follows (Stern, 2006: 148): (1) For warming up to 2 or $3{ }^{\circ} \mathrm{C}$, some models predict beneficial, others harmful impacts, though in general any benefits are concentrated in rich countries, while costs of climate change fall particularly on poor countries. (2) For global warming above 2 or $3{ }^{\circ} \mathrm{C}$, the models agree in the assessment that climate change would reduce long-term well-being, leading to lower levels of consumption and per capita income. Besides the consensus on the negative impact and the higher costs suffered by low-income regions (Africa and Asia), the models strongly disagree on the level of human-induced damage, with estimates ranging from less than $1 \%$ to $>10 \%$ of WGDP. Even after standardizing assumptions and scenarios in different models, the range of variation in the results is very significant. For example, considering the U.S. economy, the standardization of assumptions in five IAMs resulted in estimates of climate change costs ranging from $0.4 \%$ to $2.2 \%$ of GDP (Spash 2002: 171). The IAMs have sometimes rendered contradictory results with respect to the same sector. For example, Chinese agriculture sometimes appeared as a major loser (Fankhauser, 1995), other times as a major winner (Nordhaus, 1998) of climate change.

Discrepancies also occur when calculating the so-called "social cost of carbon," that is, the net present monetary value of damage caused by an additional increase in $\mathrm{CO}_{2}$ emissions. Under the assumptions of neoclassical economics, the marginal cost of the damage would be equivalent to a carbon tax that would internalize the externality posed by climate change and achieve an efficient solution. However, as documented by Tol (2008, 2009), there is great uncertainty in the estimated social cost of carbon. More than 50 studies, involving 200 different estimates, provide a mean estimate of $\$ 105$ (U.S. dollars of 1995) per metric ton of carbon, with a standard deviation of $\$ 243$, and a mode of only $\$ 13$ (Tol 2009, p. 41). 


\subsection{Limitations of IAMs}

The lack of robustness of results of different IAMs indicates the limitations of the neoclassical approach, which constitutes the theoretical base of most IAMs; the variety of so-called ad hoc assumptions (often qualified as "heroic" by their own authors), and the controversial nature of the methods to estimate the monetary value of non-market costs and benefits (mortality, morbidity, damage to ecosystems, etc.). These features explain why many contributions of this type of macroeconomics-oriented IAMs have been criticized for their dubious political usefulness and limited scientific soundness (Spash, 2002; Courtois, 2004; Ackerman et al., 2009; Stanton et al., 2009). Important shortcomings of IAMs are the following:

(1) Lack of transparency to explain and justify the assumptions behind the estimates. This weakness has been noted even by one of the most prolific authors in the development of IAMs (Tol, 2002: p. 48). It is almost impossible to avoid value judgments in developing models for assessment of impact; at most, the value judgements are implicit. However, models are often built without any explicit ethical consideration, as if that would imply constructing them with scientifically proven facts only.

(2) Questionable treatment of uncertainty and discounting of the future. To compare costs or benefits from effects suffered or enjoyed by future generations requires using an appropriate discount rate for obtaining present values. Any positive discount rate implies that the welfare or interest of present generations weighs more in the decision than the welfare of future generations. In most IAMs, discount rates between $3 \%$ and $6 \%$ are used. The rationale is that future generations would benefit from economic growth and thus they would consume more goods and services and therefore obtain more utility. However, the available scientific information suggests that future problems of scarcity of resources and saturation of natural sinks are closely related to economic growth, which would be reaching limits imposed by natural resources and other natural variables. The likely consequences of climate change also worsen the environmental and social conditions for human existence. In this context, adopting the precautionary principle as a guide to minimize the worst future scenarios, indeed, seems to be the rational choice. A value judgment that assumes a positive discount rate is questionable, in particular because from an ethical point of view, only equal weight of all generations would be defensible, which means a zero discount rate. In any case, simply by varying the discount rate of what an uncertain future holds, the results of IAMs are significantly modified. As explained by Ackermann et al. (2009, p. 310),

\footnotetext{
The upshot of these alternative ways of characterizing the intergenerational decision-making problem is that the normative assumptions that are made about how future generations are treated are as important as the technical details. Not having happened yet, the future is unobservable; moreover, there are no reliable, universally accepted economic laws that shape our understanding of the future in the way that the laws of natural science do for the physical reality of climate change. When it comes to economics, there is no escape from value-laden assumptions about the future. Furthermore, consciousness and intergenerational concern are influenced by social and political discourse. In the case of climate policy where fundamental values and ethical principles are at stake, it is an abdication of responsibility for economists to act as if peoples' preferences are simply given and fixed.
}

(3) Assumption of perfect substitutability between manufactured capital and "natural" capital in the production of goods and services. In IAM models, a basic assumption is that natural resources, ecosystems, natural sinks or other elements of the so-called natural capital can be substituted by manufactured capital (machines, chemical procedures, etc.), so that reductions or exhaustions in the stock of natural capital could be offset by increases in the stock of manufactured capital to keep intact the capacity of producing goods and services. Some ecological economists (Daly, 1996; Neumayer, 1999, 2007) have shown how the relation between the two stocks of "capital" is one of complementariness, with possibilities of substitution being rare in most production processes. It does not help to expand a fleet of fishing boats to compensate for the disappearance of fish stocks. In the context of climate change, where anthropogenic processes imply a significant deterio- 
ration of the stocks of natural and manufactured capital, maintaining the assumption of perfect substitutability between them is a major limitation.

4) Finally, the way IAMs estimate monetary costs of non-market effects can lead to skepticism about policies based on the results of the models. The estimation of non-market values is supported in methods of "willingness to pay" (WTP) for desired items or "willingness to accept" (WTA) a compensation for undesired occurrences. These methods of WTP and WTA have theoretical weaknesses that are well known in ecological and environmental economics. For instance Tol (2009, p. 39) has explained the difficulties of WTP and WTA methods in an intergenerational framework:

Implicitly, the policy problem is phrased as: "How much are we willing to pay to buy an improved climate for our children?" Alternatively, the policy problem could be phrased as: "How much compensation should we pay our children for worsening their climate?" This question is a different one, and the answer would be different if future generations are loss averse or distinguish between self-imposed and other-imposed risks.

Beyond the ethical and practical problems implied by the estimates, it seems there is also a conceptual mistake: the fact that we give a value to the surrounding environment and to human lives does not mean that there is also a monetary expression of this value that valuation techniques aim to find. Though many economists assume anything can be rationally attributed a monetary value, many others question the valuation of all valuable things for individuals and society in money. Indeed, when in the IPCC's Second Assessment Report (Pearce et al., 1996) money values were attributed to the environment and human life, it immediately raised a hard scientific controversy (Masood and Ochert, 1995; Meyer, 1995; Pearce, 1995; Tol, 1997; Spash, 2002). The global estimates of positive (beneficial) effects of climate change on social welfare obtained in some IAMs are the consequence of estimated welfare gains in rich countries, offsetting welfare losses in poor countries. This highlights the importance of how costs are calculated and the assumptions and methodologies used for it. As Ackerman et al. (2009, p. 305) have explained,

\begin{abstract}
Should we estimate the value of human life on the basis of the small wage differentials between more and less dangerous jobs [...]? Or, should we rely on responses to long questionnaires asking people how much they would pay to avoid small risks of death under abstract hypothetical scenarios [...]? Should we value ecosystems according to what people living nearby report they are willing to pay to preserve their scenic vistas or their favourite large animals? A non-economist could be forgiven for assuming that these are rhetorical questions. Yet these approaches are regularly applied in policy analyses to estimate monetary values for health and environmental benefits [...]. Should the value of a human life depend on individual or national income levels? Should nature located in a rich country be worth more than if it is located in a poor country? Remarkably, economists often answer "yes" to both of these disturbing questions. Values of human life differentiated by national income made a brief and unwelcome appearance in the IPCC's Second Assessment Report (1996) but appeared to be banished by the time of the Third Assessment Report (2001). Similar values, however, continue to appear in the economics literature, making their way into IAMs...
\end{abstract}

The aforementioned limitations probably explain the growing skepticism of some economists and many scientists about the usefulness of IAMs. Unease is added to skepticism sometimes, as, for example, when an expert in IAMs of climate change, Robert Mendelsohn, wrote in 2000 a disturbing letter in which he explained to Senator McCain "the facts" that with a global average warming of $5{ }^{\circ} \mathrm{C}$ during the next century, the United States would enjoy benefits ranging between 14 and 23 billion a year while damages would be only 13 billion (Courtois, 2004, p. 69).

In the Stern Review on the Economics of Climate Change (Stern, 2006) that was released for the British government on October 2006, the effects of global warming on the world economy were comprehensively discussed. Although not the first economic report on climate change, the Stern Review has been considered the most widely known and discussed report of its kind. The authors of the review made a conscious attempt to overcome the weakness of previous IAMs, improving the understanding of uncertainty issues and addressing better the risk of catastrophic scenarios. In reviewing the literature, the Stern Review (p. 148) concluded that results of previous IAMs were heavily dependent 
on how [the model] aggregates the impacts across regions, and in particular how it values costs in poor regions relative to those in rich ones. The prices of marketed goods and services, as well as the hypothetical values assigned to health and the environment, are typically higher in rich countries than in poor countries. Thus, in these models, a $10 \%$ loss in the volume of production of an economic sector is worth more in a rich country than in a poor country. Similarly, a 5\% increase in mortality, if 'values of life' are based on willingness to pay, is worth more in purely monetary terms in a rich country than a poor country, because incomes are higher in the former. Many ethical observers would reject both of these statements.

It is surprising, however, that these considerations are mostly overlooked when estimating the monetary costs of climate change, which in the Stern Review include both market and non-market costs related to health and the environment. Inconsistencies on these issues appear in the review, as illustrated by the following assertions (p. 145-146):

Economists have developed a range of techniques for calculating prices and costing non-market impacts, but the resulting estimates are problematic in terms of concept, ethical framework, and practicalities. Many would argue that it is better to present costs in human lives and environmental quality side-by-side with income and consumption, rather than trying to summarise them in monetary terms. That is indeed the approach taken across most of the Review. Nevertheless, modellers have tried to do their best to assess the full costs of climate change and the costs of avoiding it on a comparable basis, and thus make their best efforts to include 'non-market' impacts.

The contradictions and limitations of the Stern Review have been noted by ecological economists (Spash, 2007, Dietz et al. 2007; Neumayer, 2007) and to a great extent have been mentioned and even recognized by Stern himself. In any case, the main message of the Stern Review is that the overall costs, including market and non-market sectors, of climate change can be estimated to be between $5 \%$ and $20 \%$ of WGDP until 2050. But with appropriate policies and mitigation technologies, emissions could be reduced and atmospheric levels of $\mathrm{CO}_{2}$ stabilized at 450 mg kg-1 with an investment equal to $1 \%$ of annual world GDP in the same period.

\subsection{Adaptation and Mitigation Strategies}

The uncertainty in the estimates of costs should not be an obstacle to address the problem and mitigate its consequences. During the last two decades there have been many proposals and debates on mitigation of climate change, that is, on how societies could reduce GHG emissions through economic policies and technological means. Research and proposals regarding possibilities of adaptation to climate change have been much less common. In general, adaptation measures aim to reduce the vulnerability of society to severe adverse climatic events (droughts, floods, etc.), while mitigation strategies seek to reduce human emissions of GHG. Hence, it can be said that mitigation intends to protect nature from society, while adaptation is intended to protect society from nature (Stehr and von Storch, 2005, p. 537).

Until very recently, societal adjustments to climate change have been mostly unplanned and forced by circumstances. There is often a relationship between increased vulnerability to climate change and a lower degree of economic and social development that implies a lower adaptive capacity. Social and economic consequences of weather phenomena are usually worst when they interact with social events, such as armed conflicts or epidemics, or chronic conditions of land degradation, poverty or lack of public sector institutions to deal with environmental emergencies related to global warming, e.g., droughts, hurricanes or wildfires. Though conditions that make adaptation more difficult often occur in 'Third World' regions and countries-e.g., drought-related impacts of global warming in Africa have been considered particularly damaging-high-income countries with better economic and social conditions have also suffered hard hits of extreme weather events that can be connected with climate change, e.g., hurricane Katrina in the USA in 2005, and the heat waves and droughts that affected much of Europe in 2003, Eastern Europe in 2010, and Mexico and the southern USA in 2011 (IPCC, 2007b, p. 56; Hansen et al., 2012b). 
Along with adaptations forced by circumstances, there may be planned adaptations to the effects of climate change. Some are documented in the Fourth IPCC Assessment Report; for instance, the partial drainage of the Tsho Rolpa glacial lake in Nepal, changes in livelihood strategies of the Inuit in response to the melt of permafrost in northern Canada, or the consideration of sea-level rise in the management of coastal zones in the USA or in the design of infrastructure, such as the Confederation Bridge of Canada (Adger et al., 2007, p. 719).

Adaptation policies and measures include planning and management of natural resources (water and energy), influence in the operation of economic sectors (agriculture, construction and infrastructure), and reducing the direct impact of climate change on human health. Measures that have been proposed or applied are expanded rainwater harvesting and application of desalination techniques for improving water availability; adjustment of planting dates and crop variety, erosion control and soil protection through tree planting to prevent damages in agriculture; seawalls, storm surge barriers (e.g., mangroves), dune reinforcement and creation of marshlands/wetlands as buffers against sea level rise, flooding and erosion; and plans for preventing human deaths because of heat waves (IPCC, 2007b, p. 57). Of course, many of these measures and policies will only be useful to adapt or mitigate moderate climate disruption, implying small levels of warming or other alterations of the climate.

Cost-benefit analyses and analyses of cost-effectiveness have been applied sometimes in the adaptation field; they have been much more commonly applied to economic evaluations of mitigation strategies. Studies on adaptation strategies have focused primarily on adaptation to sea level rise (Fankhauser, 1995a; Yohe and Schlesinger, 1998, Tol et al., 2003, Ng and Mendelsohn 2005, Nicholls and Tol, 2006), and adaptation in agriculture (Rosenzweig and Parry, 1994; Adams et al., 2003, Reilly et al., 2003), primarily in the OECD countries (see a review in Adger et al., 2007). Taking into account the caveats on the theoretical weaknesses of these cost-benefit or cost-efficiency analyses that were explained in section 3.2, the results of these studies can be summarized as follows (Adger et al., 2007, pp. 724-725). First, coastal protection is an optimal policy in almost all cases in which the rise in sea level is less than one meter. Second, there are significant uncertainties about monetary valuations of land. Third, in agriculture, the geographical and economic context seems to be essential: some adaptation measures of low cost in poor countries (tropical), such as changes in planting dates and crop mixes, have shown significant potential, but, by themselves, would not be able to offset the damage caused by climate change.

Mitigation strategies have received increased attention in academic and institutional spheres in recent years. As part of the Fourth Assessment Report of the IPCC, Barker et al. (2007) reviewed mitigation studies as well as the potential of available technologies and technologies projected to be commercialized before 2030 for reducing GHG emissions. Table 3 contains a summary of the selected sectors and reduction potentials under different prices of one ton of $\mathrm{CO}_{2}$, applying a bottom-up approach. 5 Considering the selected sectors and estimated potential for mitigation, it shall be noted that:

(i) even without considerations or assumptions on the uncertain future, studies show the existence of pure benefit (negative costs) associated with mitigation measures that save economic resources and might reduce GHG emissions by 6 gigatons of $\mathrm{CO}_{2}$-equivalents ${ }^{6}$ in 2030; possibilities of such benefits are mainly in the areas of construction, electricity production, and energy consumption in transport;

\footnotetext{
${ }^{5}$ According to the Glossary of Terms used in the IPCC Third Assessment Report, the terms 'top' and 'bottom' are "shorthand for aggregate and disaggregated models. The top-down label derives from how modelers applied [...] techniques to historical data on consumption, prices, incomes, and factor costs to model final demand [...], and supply from main sectors, like the energy sector, transportation, agriculture, and industry. Therefore, top-down models evaluate the system from aggregate economic variables, as compared to bottom-up models that consider technological options or project-specific climate change mitigation policies."

${ }^{6} \mathrm{~A}$ gigaton equals $10^{9}$ tons. Emissions are estimated in $\mathrm{CO}_{2}$-equivalents to measure together emissions of different GHG. In the rest of the chapter $\mathrm{Gt} \mathrm{CO}_{2}$-eq. is the abbreviation for gigatons of $\mathrm{CO}_{2}$-equivalents.
} 
(ii) there is also a broad consensus that no single technology option is able to provide all potential mitigation for each sector; and

(iii) these potentials for mitigation and emission reductions are supported only by technological progress, without incorporating the potential mitigation associated with non-technical options, such as changing consumption models and lifestyles. Changes in consumption patterns and lifestyles are particularly relevant, though.

Besides the reduction in annual emissions of $6 \mathrm{Gt} \mathrm{CO}_{2}$-eq that could be obtained in 2030 from mitigation measures that save economic resources, Barker et al. (2007, p. 621) estimated additional mitigation potentials in 2030 depending on different carbon prices. For prices of less than 50 US\$ per ton of $\mathrm{CO}_{2}$-eq, the total reduction would be 13 to $26 \mathrm{Gt} \mathrm{CO2-eq} \mathrm{(this} \mathrm{includes} \mathrm{the} \mathrm{aforemen-}$ tioned $6 \mathrm{Gt}$ of reduction and would correspond to 29\%-59\% of global GHG emissions in 2005); for higher prices of 50 to $100 \mathrm{US} \$$ per ton of $\mathrm{CO}_{2}$-eq, the mitigation potential would rise 16 to $31 \mathrm{Gt}$ CO2-eq (equivalent to $36 \%-70 \%$ of global emissions in 2005).

Reaching these goals requires a combination of technological and sectoral policy options, including improvements in energy efficiency and fossil fuel reduction and substitution, land use and transport planning, efficient lighting, improved crop management and soil conservation, reforestation and sustainable forest management, etc. This should be developed in conjunction with appropriate incentive and disincentive mechanisms (subsidies for ecological reconstruction of economy, taxes on carbon, energy planning, financial incentives, etc.).

It is obvious that the potential for mitigation exists regardless of difficulties and weaknesses of the monetary quantification for it. But three considerations shall be added. First, the fact that after these mitigation estimates were performed, the global economy suffered a serious economic crisis, the so-called Great Recession, which poses serious questions about the realism of the rate of global economic growth assumed in most scenarios. As noted in section 2, the drop in WGDP implied by the Great Recession was accompanied by a momentary reduction in the growth rate of $\mathrm{CO}_{2}$ emissions. Second, the excessive reliance on technology to address climate change often ignores one of the most important lessons learned from history of technological progress: the systematic appearance of the "rebound effect" corresponding to the so-called Jevons paradox. This implies that more efficiency in the use of a resource does not reduce but tend to increase the use of the resource (Blake, 2005; Polimeni et al., 2008). In this regard, for example, although energy efficiency in the use of fossil fuels has improved in recent decades, $\mathrm{CO}_{2}$ emissions have not been declining but steadily increasing. Technological improvements increasing the efficiency of use of a resource tend to reduce the unit price of the resource and thus they tend to increase, rather than decrease, the quantity consumed. In this way, increasing efficiency in the use of something would tend to increase the overall physical consumption of it (and activities related), and therefore also the energy (emissions) and materials used to produce it. In a peak oil scenario, that is, under the assumption that the highest possible rate of extraction of petroleum has been reached (the International Energy Agency says production of conventional crude oil peaked in 2006), the effect of the Jevons paradox could be very harmful, because it would keep the level of use of fossil fuels, and therefore rising or at least not declining $\mathrm{CO}_{2}$ emissions, in spite of rising prices of fossil fuels.

It seems clear that one route to mitigation that should be explored more systematically is what IPCC calls "non-technical options," that is, changes in consumption patterns and lifestyles whose potential is not considered in the mitigation scenarios. For instance, there is increasing evidence of the importance of changes in patterns of individual mobility. For an identical volume of transport, public transportation, walking, or bicycling (or sea/land carriers instead of airborne vessels) saves emissions compared with car transportation. Many of these options have also large potentials as health-enhancing behaviors.

The conclusion is that these mitigation issues have to do with technology, but given the limitations of technological fixes, it is necessary not to overlook the possibility of socio-economic changes to modify economic mechanisms and incentives to advance towards a world with a stable climate, compatible with justice and human progress. According to the IPCC, it can be expected with high 
confidence that even a combination of aggressive mitigation and significant investment in adaptive capacity could be overwhelmed by the end of the present century. Until around 2050, it is likely that global mitigation efforts designed to cap $\mathrm{CO}_{2}$ concentrations at $550 \mathrm{mg} \mathrm{kg-1}$ would benefit developing countries significantly, and developed countries would also likely obtain significant benefits from an adaptation-mitigation intervention portfolio. However, by 2100, climate change will likely produce significant harm across the globe, even if aggressive mitigation strategies were implemented in combination with significantly enhanced adaptive capacity (Yohe et al., 2007).

\section{Agriculture and climate change}

As economic development takes place, the contribution of agriculture to GDP strongly decreases. It is presently only a few percentage points in high-income countries, though much higher in the developing world (according to World Bank, 1.2\% in 2010 in the USA, 17.2\% in India). Leaving aside monetary measures, the sector is very important not only because it provides food for the humankind, but also because it provides work to $40 \%$ of the world's active population (FAO, 2011). In developing countries, the proportion working in agriculture is quite higher, up to a range of $60 \%$ to $75 \%$.

In recent decades, there have been major technological changes in agriculture, usually originated in developed countries and increasingly widespread worldwide through the "green revolution." The following are some important characteristics of agriculture and the global system of food production in relation to climate change.

1. There has been a major increase in agricultural production and yields since the 1950s (FAO, 2000). However, this productivity growth has changed one of the features of the very nature of agriculture. From being mostly an activity of production of food that relied on renewable energy sources-mainly the sun-agriculture increasingly became an economic activity producing food and increasingly non-food products in a way highly dependent on fossil fuels. In the long run, this dependence on exhaustible energy sources is a threat for the future supply of food for the world's population. Technological change in agriculture has implied widespread application of synthetic fertilizers, high-yield varieties and farming systems of large-scale, all of which have led many authors and institutions to question the sustainability of modern agriculture (Gliesmann, 1990; Pimentel and Pimentel, 1996; Altieri, 2000). From the point of view of energy balances, it is paradoxical that organic or traditional agriculture is more energy-efficient than modern agricultural production (Pimentel, 1992, 2005; Carpintero and Naredo, 2006).

2. Something similar applies to livestock production. Industrial farming based on concentrated animal-feeding operations has led to increased demand of feed grain, which in many developing countries has been the reason for increasing deforestation to expand the cultivation of animal feed, which is generally exported to developed countries.7 Cattle in solitary confinement no longer pasture and crops of feed grain require major inputs of fossil energy (for producing fertilizers, using machinery, etc..), inducing GHG emissions; the consequences are an increase in energy inefficiency in obtaining food from the trophic chain, and an increased contribution to climate change. Compared with vegetables and grains, meat is a very energy-inefficient (and unhealthy beyond given thresholds) product as human food, and, as mentioned, its production strongly generates GHG emissions. Since the 1990s, investigations of the economic and environmental aspects of livestock production have originated many interesting analyses of the ecological consequences associated with different feeding models and patterns of consumption (Pimentel et al., 1973, Pimentel and Pimentel, 1979; Brown and Kane, 1994; Kendal and Pimentel, 1994, Goodland, 1997, Bouma et al., 1998; White, 2000; Seidl, 2000; Gerbens-Leenes, Nonhebel, Ivens, 2002; Gerbens-Leenes, Nonhebel, 2002). For instance, since the cattle no longer pasture and need more and more grain and

\footnotetext{
${ }^{7}$ A typical example is soybean production in Argentina that according to FAO increased between 1980 and 2010 from 3.5 to 62.7 million tons, with the area dedicated to the crop expanding from 2 to 18 million hectares (faostat.fao.org). It has been also estimated that 16 million hectares of forest had been lost to soybean production; $95 \%$ of the soy presently produced is genetically modified.
} 
forage crops, a human meat diet requires at present about three times more cultivated land than a vegetarian one (Penning de Vries, 1995). With meat content as in the average U.S. diet, the present agricultural world production would be able to feed about 2.5 billion people, that is, about $1 / 3$ of the people alive today. "This is why it is so important for the world to remain low down in the food chain, for those high to descend, and to discourage people from moving up" (Goodland, 1997, p. 191). For these and other reasons, the sustainability of intensive livestock production model has been questioned (FAO, 2010).

3. During the past two decades, an expansion of international trade in agricultural products has occurred as part of a process of consolidation of a globalized agricultural model (Delgado, 2011). As part of this process, food imports have grown dramatically in many countries that formerly imported little or no food. For example, in Asia, food imports increased 75\% between 2000 and 2010 (FAO, 2011). Imports of grain to poor countries increasingly threaten peasant farming and raise the vulnerability of rural communities, compromising their food security. On the other hand, this trade is associated with a significant generation of GHGs in long-distance transportation.

4. Finally, it shall be noted as a major aspect of the present intensive agricultural system the high degree of concentration in agricultural markets of both products and inputs. For instance, the 10 largest companies that provide agricultural inputs sell $67 \%$ of commercial seed, $63 \%$ of livestock medicines, and 89\% of agrochemicals (ETC Group, 2008). The oligopolistic nature of the world food market strengthens the incentives for the consolidation of the intensive farming model. It is thus a major obstacle to be overcome if agriculture is going to transform in a direction consistent with mitigation of climate change.

Agriculture impacts global warming through GHG emissions in two ways. On one hand, there are direct emissions of GHG related to agricultural activity. $\mathrm{CH}_{4}$ emissions result from digestive processes of livestock, rice cultivation by flooding, or stored manure; $\mathrm{NO}_{2}$ emissions come from the use of nitrogen fertilizers; $\mathrm{CO}_{2}$ results mainly from the degradation of organic matter by burning crop residues, manure application, and aggressive tillage practices (IPCC, 2001). These emissions amounted in recent years to $10 \%$ to $12 \%$ of total anthropogenic GHG emissions, or 5.1 to $6.1 \mathrm{Gt}^{\mathrm{CO}_{2}}$ eq annually; of these $6.1 \mathrm{Gt} \mathrm{CO}_{2}$-eq, about 3.3 would be attributable to $\mathrm{CH}_{4}$ while $\mathrm{NO}_{2}$ would contribute $2.8 \mathrm{Gt} \mathrm{CO}_{2}$-eq (Smith et al., 2007). Direct emissions of $\mathrm{CO}_{2}$ from agriculture are less important because, in general, exchanges of $\mathrm{CO}_{2}$ from agricultural land to the atmosphere are approximately balanced by the capture of $\mathrm{CO}_{2}$ by growing plants, and the net flux is small.

Things are very different regarding indirect emissions of GHG from agriculture. These include emissions from land use change, when natural ecosystems (forests, wetlands, etc.) are transformed into cultivated land. The IPCC (2000) estimated these indirect emissions to amount during 19861998 to $5.8 \pm 2.9 \mathrm{Gt} \mathrm{CO}_{2}$-eq per year. Houghton (2008) also suggested a total global flux of $5.8 \mathrm{Gt}$ $\mathrm{CO}_{2}$-eq/year during the $1990 \mathrm{Os}$, and $5.4 \mathrm{Gt} \mathrm{CO}_{2}$-eq/year during the first half of the past decade.

Considering these estimates, it seems the indirect emissions of GHG because of land conversion to agriculture are similar in magnitude to the direct emissions. The sum of direct and indirect emissions would thus represent annually about a fourth, 24\%, of GHG global emissions. It should be noted that the distribution of these emissions is very uneven, with $74 \%$ of agricultural GHG emissions coming from low-income countries (Smith et al., 2007, p. 503).

Global warming is affected by agricultural activity, but, of course, global warming is also affecting agriculture. Among the most important effects considered (IPCC, 2007b) are the following: (1) decreased yields in warmer environments, and increased yields in colder ones because of longer growing season and $\mathrm{CO}_{2}$ fertilization. Regarding the latter, recent research has indicated that ground level ozone emissions generated in the same combustion that emits $\mathrm{CO}_{2}$ could offset the positive impact of longer growing seasons and $\mathrm{CO}_{2}$ fertilization, and even it might cause a small net reduction in agricultural productivity (Reilly et al., 2007, cited by Ackerman, 2009, p. 306); (2) increased insect outbreaks; (3) increased evapotranspiration and greater risk of wildfires; (4) crop damage, erosion and land degradation, with the consequence of lower yields, and increased live- 
stock mortality; (5) deterioration of water quality (salinity of irrigation water) and quantity (increased scarcity caused by reduced rainfall and more frequent droughts).

The Fourth Report of the IPCC (2007a) proposed a series of mitigation measures for agriculture that could achieve considerable potential GHG reduction by 2030 (Table 3) under different carbon price assumptions (Smith et al., 2007, p. 515). Measures and policies proposed to achieve this reduction (many of which are analyzed in other chapters of this book) include crop management (nutrient, tillage and residue management), management of organic soils, restored degraded lands, livestock grazing, land management, pasture improvement, and manure management. But as noted by Smith et al. (2007, p. 499), the key to success lies in soil carbon sequestration: "Soil carbon sequestration (enhanced sinks) is the mechanism for most of the mitigation potential, with an estimated $89 \%$ contribution to technical potential. Mitigation of $\mathrm{CH}_{4}$ emissions and $\mathrm{N}_{2} \mathrm{O}$ emissions from soils account for $9 \%$ and $2 \%$, respectively, of the total mitigation potential." However, total emissions of GHG from soil loss on account of erosion caused by intensive farming worldwide are very concerning (Lal, 2004; Lal, et al., 2004).

There are ways as the aforementioned ones to restore soil carbon and improve food production and conservation of agro-ecosystems. Indeed, a low-carbon (organic) agriculture has features that contribute to mitigating climate change and improving food system sustainability. As explained by Nigli et al. (2009, p. 2). organic agriculture "strongly reduces the reliance on external inputs by (i) recycling wastes as nutrient source; (ii) using nitrogen-fixing plants; (iii) improving cropping systems and landscapes; (iv) avoiding synthetic pesticides; and (v ) integrating crops and animals into a single farm production sector and including grass clover leys for fodder production, while avoiding purchase of feed concentrates."

The task of conserving and increasing the carbon content of soils implies modifying practices of intensive agriculture that are already ingrained, and showing that it is not only desirable but also possible to move towards agroecology, or low-carbon agriculture (Gliesmann, 1990; Altieri, 2002; Halberg, et.al., 2006; Badgley et al., 2007; UNEP-UNCTAD, 2008; Nigli et al., 2009; Willer and Kilcher, 2009).

\section{Conclusions}

Seven years ago, several national academies asserted in a joint statement that the scientific understanding of climate change is now sufficiently clear to justify nations taking prompt action (National Academies, 2005). However, dozens of international meetings and hundreds of hours of discussion later have only yielded ineffective agreements and an increasing inability of intergovernmental bodies to put in place policies that contribute to the "substantial and long-term reduction in global GHG emissions" that was requested by the national academies. In the meanwhile, emissions have continued to rise, even at faster rates, responding to the fluctuations of the global economy rather than to the half-hearted policies enacted in some countries to curb them.

Since the 1990s, there has been a long-standing debate about which environmental policy is best to combat climate change. Emission permits trading and the implementation of a carbon tax are the major options in the public debate (Hansen, 2009; Krugman, 2009). At present, there is some experience on emission permits trading since the European Trading Scheme was implemented in the European Union in 2005.

The European Trading Scheme has yielded very poor results and has been seen as plagued by problems of theoretical design (Spash, 2010; Aldy and Stavins, 2011; Corporate Europe Observatory, 2011). The scheme has failed to reduce emissions and the emissions market is at present virtually inactive, with a price of emissions at almost zero. Because of this "oversupply," there is no incentive to reduce the emissions of $\mathrm{CO}_{2}$ by companies. The granting of free emission permits to the industry, when the scheme was implemented in 2005, allowed some companies to sell later the permits that they had received gratis during the first years, obtaining significant windfall profits in the process. At any rate, the global economic crisis that started in 2007 and is still going on or even worsening in Europe, has reduced industrial activity and the "excess emissions" unused have 
generated this oversupply, leading the price per ton of $\mathrm{CO}_{2}$ to plummet, so that, presently, there is no incentive for emitters to adopt strategies to reduce $\mathrm{CO}_{2}$ emissions.

The theoretical shortcomings and poor results of trading of emission permits enhance the position of those who propose a carbon tax as the main tool to fight global climate change. This tax would be a key element of a green tax reform because it would reduce emissions by discouraging consumption of "carbon-rich" commodities and therefore promoting recycling, reuse and innovation toward production and consumption of "carbon-poor" commodities. Such as proposed, for instance, by Hansen (2009), the carbon tax would be fiscally neutral, so that would be $100 \%$ returned to the public on a per capita basis. Other proponents of the carbon tax see it as a means to obtain resources required to finance the ecological transformation of industrial society, or to improve the fairness of the overall tax burden. At any rate, there have been only some timid steps in Australia, in the European Union and in Scandinavian countries toward the implementation of a carbon tax (Andersen and Ekins, 2009; Bakker, 2009). But the business community is strongly opposed to it and in the USA, even schemes for permits trading are considered out of question by most decision-makers. Climate change deniers are still common in public debates and many politicians, business leaders and other "leaders of opinion" continue pointing to supposed inconsistencies of the science of global warming and to the lack of agreement among scientists with expertise on the issue. But, why is it so?

Energy inputs and therefore $\mathrm{CO}_{2}$ emissions are almost constantly implied by economic activities that generate monetary value, and such activities are the core of the working of our economic system. As economist Wesley C. Mitchell once explained, activity in a modern money economy is immediately aimed and guided, not by the quest of satisfactions or satisfaction of needs, but by the quest of profits, so that the major thrust of entrepreneurial activity is the money gain (Mitchell, 1913, p. 21-22). Though many of the economic activities presently demanded by consumers are possible with a considerable restriction of emissions, there are implied reductions in profit that the affected businesses will oppose as much as possible. But emissions of $\mathrm{CO}_{2}$ are implied indirectly by many business activities and, furthermore, oil, coal, and car manufacturing industries-that benefit from products directly contributing to global warming-form a powerful lobby of corporations and national governments. For these reasons, effective policies to curb emissions have faced once and again insurmountable obstacles.

Perhaps a lesson can be learned from the fight of civil society and public health professionals worldwide against the marketing of tobacco products. This fight had to push the health interest of a diffuse public against the concrete interests of tobacco growers, cigarette manufacturers and even governments obtaining tax revenues from tobacco sales (Christoffel and Christoffel, 1989). The scientific community and the public heath advocates had to overcome major campaigns of tobacco manufacturers to deny either the science showing the harmful effects of smoking or the right of society to regulate sales of an addictive drug. Even now, tobacco manufacturers are still powerful enough to promote legally and sell their addictive drugs without restriction in many countries. But cigarettes are just one product, while policies for regulating emissions would affect directly hundreds of commodities and, indirectly, almost all of them. That explains why curbing emissions meets almost insurmountable obstacles. However, in the same way a 'healthy smoker' is an oxymoron, a sustainable society is incompatible with the present dynamics that are changing our atmosphere and the global climate.

We are writing this chapter during a summer of global news of extremely hot temperatures, in which $80 \%$ of the USA is abnormally dry, with a drought which according to the National Climatic Data Center is the worst in 56 years. June 2012 was the $10^{\text {th }}$ driest June on record going back to 1895 (Associated Press, 2012). Damaging wildfires are all around and crops, pastures and rangeland have deteriorated at an alarming rate.

In our opinion, to keep climate change from reaching levels implying irreversible consequences for both humanity and nature is a key undertaking for the following decades; it is probably of no less significance than preventing a third world war. Whether or not advancing toward that goal is 
possible under the present economic and political conditions, only time will tell. For the scientific community, the task at hand is to show how things are. Under the tenets of democracy, it is for the people to decide what is to be done. 


\section{REFERENCES}

Ackerman, F., S. De Canio, R. Howarth, and K. Sheeran. 2009. Limitations of the integrated assessment models of climate change. Clim. Change 95:297-315.

Adam, D. 2009. Stern attacks politicians over climate 'devastation'. The Guardian, March 13.

Adams, R.M., B.A. McCarl, and L.O. Mearns, 2003. The effects of spatial scale of climate scenarios on economic assessments: An example from U.S. agriculture. Clim. Change 60:131-148.

Adger, W.N., S. Agrawala, M.M.Q. Mirza, C. Conde, K. O’Brien, J. Pulhin, R. Pulwarty, B. Smit, and K. Takahashi. 2007. Assessment of adaptation practices, options, constraints and capacity. p. 717-743. In: M.L. Parry, O.F. Canziani, J.P. Palutikof, P.J. van der Linden, and C.E. Hanson (eds.) Climate change 2007: Impacts, adaptation and vulnerability. Contribution of Working Group II to the Fourth Assessment Report of the Intergovernmental Panel on Climate Change, Cambridge University Press, Cambridge, UK.

Aldy J., and R. Stavins. 2011. The promise and problems of pricincg carbon: Theory and experience. Center for Business and Government, Harvard Kennedy School, WP RPP-2011-06.

Altieri, M. A. 1995. Agroecology: The science of sustainable agriculture. Westview Press, Boulder, CO.

Andersen, M., and P. Ekins (eds.). 2009. Carbon energy taxation. Lessons from Europe. Oxford University Press. New York.

Associated Press. 2012. Drought is the worst in 56 years. The New York Times, July 17, p. A16.

Ayres, R.U., and J. Walter. 1991. The greenhouse effect: Damages, costs and abatement. Environm. Resource Econ. 1(3): 237-70.

Badgley, C., J. Moghtader, E. Quintero, E. Zakem, M.J. Chappell, K. Avilés-Vàzquez, A. Samulon, and I. Perfecto. 2007. Organic agriculture and the global food supply. Renewable Agric. Food Systems 22:86108.

Bakker, A. (ed.). 2009. Tax and environment. A world of possibilities. International Bureau of Fiscal Documentation. Amsterdam.

Barker, T., I. Bashmakov, A. Alharthi, M. Amann, L. Cifuentes, J. Drexhage, M. Duan, O. Edenhofer, B. Flannery, M. Grubb, M. Hoogwijk, F. I. Ibitoye, C. J. Jepma, W.A. Pizer, and K. Yamaji. 2007. Mitigation from a cross-sectoral perspective. p. 619-690. In: B. Metz, O.R. Davidson, P.R. Bosch, R. Dave, L.A. Meyer (eds.) Climate change 2007: Mitigation. Contribution of Working Group III to the Fourth Assessment Report of the Intergovernmental Panel on Climate Change. Cambridge University Press, Cambridge, U.K., and New York, NY.

Barrett, S. 2008. The incredible economics of geoengineering. Environm. Resource Econ. 39:45-54.

Blake, A. 2005. Jevons' paradox. Ecol. Econ. 54:9-21.

Bouma, J., G. Varallyay, and N.H. Batjes. 1998. Principal land use changes anticipated in Europe. Agric. Ecosyst. Environm. 67:103-119.

Carpintero, O., and J.M. Naredo. 2006. Sobre la evolución de los balances energéticos de la agricultura española (1950-2000) [Energy balances of Spanish agriculture (1950-2000)]. Historia Agraria 40:531554.

Carter, S.B., S.S. Gartner, M.R. Haines, A.L. Olmstead, R. Sutch, and G. Wright. 2006. Historical statistics of the United States: Millennial edition online. Cambridge University Press, New York.

Chandr Jaunky, V. 2011. The $\mathrm{CO}_{2}$ emissions-income nexus: evidence from rich countries. Energy Policy 39:1228-1240.

Christoffel, T, and K.K. Christoffel. 1989. The consumer product safety commission's opposition to consumer product safety: Lessons for public health advocates. Am. J. Public Health 79:336-339.

CDIAC. 2009. Carbon dioxide information analysis center (www.cdiac.ornl.gov, data downloaded in 2009).

Cline, W.R. 1992. The economics of global warming. Institute for International Economics, Washington, DC.

Conway, T.J., P.P. Tans, L.S. Waterman, K.W. Thoning, D.R. Kitzis, J.A. Masarie, and N. Zhang. 1994. Evidence for interannual variability of the carbon cycle from the national oceanic and atmospheric administration/Climate monitoring and diagnostics laboratory: global air sampling network. J. Geophys. Res. 99:22831-22855.

Copenhagen Consensus. 2012. Copenhagen consensus webpage (www.copenhagenconsensus.com, consulted July 2012). 
Corporate Europe Observatory. 2011. EU ETS: failing at the third attempt. Climate and Energy. (www.corporateeurope.org/news/eu-ets-failing-third-attempt).

Courtois, P. 2004. The status of integrated assessment in climatic policy making: an overview of inconsistencies underlying response functions. Environm. Sci. Policy, 7(1):69-75.

Daly, H.E. 1996. Beyond growth. The economics of sustainable development. Beacon Press, Boston.

de Bruyn, S.M., J.C.J.M. van den Bergh, and J.B. Opschoor. 1998. Economic growth and emissions: Reconsidering the empirical basis of environmental Kuznets curves. Ecol. Econ. 25:161-175.

Delgado, M. 2010. El sistema agroalimentario globalizado: imperios alimentarios y degradación social y ecológica. Rev. Econ. Crítica 10:32-61.

Dietz, S., C.W.Hope, and N. Patmore. 2007. Some economics of "Dangerous" climate change: Reflections on the Stern review. Global Environm. Change 17:311-325.

Dijkgraaf, E., and H.R.J. Vollebergh. 2005. A test for parameter heterogeneity in $\mathrm{CO} 2$ panel EKC estimations. Environm. Resource Econ. 32:229-239.

Dinda, S., D. Coondoo, and M. Pal. 2004. Air quality and economic growth: An empirical study. Ecol. Econ. 34:409-423.

Ekins, P. 1997. The Kuznets curve for the environment and economic growth: Examining the evidence. Environm. Planning 29:805-830.

ETC Group. 2008. Who owns nature?, www.etcgroup.org.

Fankhauser, S. 1995. Valuing climate change: The economics of the greenhouse. EarthScan, London.

FAO. 2000. The state of food and agriculture. Rome.

FAO. 2010. The state of food and agriculture. Rome.

FAO. 2011. The state of food and agriculture. Rome.

Gerbens-Leenes, P.W., and S. Nonhebel. 2002. Consumption patterns and their effects on land required for food. Ecol. Econ. 42:185-199.

Gliessman, S.R. (ed.). 1990. Agroecology: Researching the ecological basis for sustainable agriculture. Springer-Verlag, New York.

Goodess, C.M., C. Hanson, M. Hulme, and T.J. Osborn. 2003. Representing climate and extreme weather events in integrated assessment models: A review of existing methods and options for development. Integrated Assess. J. 4(3):145-171.

Goodland, R. 1997. Environmental sustainability in agriculture: Diet matters. Ecol. Econ. 23:189-200.

Hansen, J. 2009. Cap and fade. The New York Times, December 7. (www.nytimes.com/2009/12/o7/opinion/o7hansen.html?_r=2).

Hansen, J., M. Sato, and R. Ruedy. 2012a. Public perception of climate change and the new climate dice. The Environmentalist. (climate.the-environmentalist.org/2012/04/public-perception-of-climate-changeand.html\#page2).

Hansen, J.E., and M. Sato. 2012b. Paleoclimate implications for human-made climate change. p. 21-48 In: A. Berger, F. Mesinger, and D. Sijacki (eds.) Climate change: Inferences from paleoclimate and regional aspects. Springer, New York.

Halberg, N., T.B. Sulser, H. Høgh Jensen, M.W. Rosegrant, and M.T. Knudsen. 2006. The impact of organic farming on food security in a regional and global perspective. CABI Publishing, Wallingford, U.K.

Holtz-Eakin, D., and T. Selden. 1995. Stoking the fires? $\mathrm{CO}_{2}$ emissions and economic growth. J. Public Econ. 57:85-101. 
IPCC. 1996. Second assessment report: Climate change 1995. IPCC. Geneva.

IPCC. 200o. Land Use, Land-Use Change, and Forestry. [Robert T. Watson, Ian R. Noble, Bert Bolin, N. H. Ravindranath, David J. Verardo and David J. Dokken Eds.], Cambridge University Press, UK.

IPCC. 2001. Climate Change 2001: Synthesis Report. A Contribution of Working Groups I, II, and III to the Third Assessment Report of the Integovernmental Panel on Climate Change [Watson, R.T. and the Core Writing Team (eds.)]. Cambridge University Press, Cambridge, United Kingdom, and New York, NY, USA.

IPCC 2007a: Climate Change 2007: Mitigation. Contribution of Working Group III to the Fourth Assessment Report of the Intergovernmental Panel on Climate Change [B. Metz, O.R. Davidson, P.R. Bosch, R. Dave, L.A. Meyer (eds)], Cambridge University Press, Cambridge, United Kingdom and New York, NY, USA.

IPCC. 2007b. Climate Change 2007: Synthesis Report. Contribution of Working Groups I, II and III to the Fourth Assessment Report of the Intergovernmental Panel on Climate Change [Core Writing Team, Pachauri, R.K and Reisinger, A. (eds.)]. IPCC, Geneva, Switzerland.

Kendal, H.W., and D. Pimentel. 1994. Constraints on the expansion of global food supply. Ambio 23:198-216.

Krugman, P. 2009. Unhelpful Hansen. New York Times, December 7. (krugman.blogs.nytimes.com/2009/12/07/unhelpful-hansen).

Krugman, P. 2011. Green economics: How we can afford to tackle climate change. The New York Times Magazine, April 7, p. 34-49.

Lal, R. 2004. Soil carbon sequestration impacts on global climate change and food security. Science 304 (5677):1623-1627.

Lal, R., M. Griffin, J. Apt, L.M. Lave, and M. Granger. 2004. Managing soil carbon. Science 304:5669.

Le Quéré, C., M.R. Raupach, J.G. Canadell, G. Marland, and L.E.A. Bopp. 2009. Trends in the sources and sinks of carbon dioxide. Nature Geoscience 2:831.

Lomborg, B. (ed.). 2004. Global crises, global solutions. Cambridge University Press, New York.

Lu, J., G.A. Vechhi, and T. Reichler. 2007. Expansion of the Hadley cell under global warming. Geophys. Res. Letters 34 (6):L06805.

Maddison, A. 2001. The world economy: A millennial perspective. Organisation for Economic Co-Operation and Development, Paris.

Martinez-Zarzoso, I., and A. Bengochea-Morancho. 2004. Pooled mean group estimation for an environmental Kuznets curve for $\mathrm{CO}_{2}$. Econ. Letters 82:121-126.

Masood, E., and A. Ochert. 1995. UN climate change report turns up the heat. Nature 378:19.

McCormick, R.E. 2004. The relation between net carbon emissions and income. p. 173-202. In: T.L. Anderson (ed.) You have to admit it's getting better: From economic prosperity to environmental quality. Hoover Institution Press, Stanford, CA.

Mendelsohn, R.O., W.N. Morrison, M.E. Schlesinger, and N.G. Andronova. 1998. Country-specific market impacts of climate change. Clim. Change 45(3-4):553-569.

Menne, M.J., C.N. Williams, and R.S. Vose. 2009. The US historical climatology network monthly temperature data, Version 2. Bull. Am. Met. Soc. 90:993-1007.

Meyer, A. 1995. Economics of climate change. Nature 378:433-433.

Mitchell, W.C. 1913. Business cycles. (Reprinted by Burt Frankiln, New York, 1970.)

Müller-Fürstenberger, G., and M. Wagner. 2007. Exploring the environmental Kuznets hypothesis: Theoretical and econometric problems. Ecol. Econ. 62:648-660.

Nakicenovic, N. 1996. Decarbonization: Doing more with less. Technol. Forecast. Soc. Change 51:1-17.

National Academies. 2005. Joint Science Academies' statement: Global response to climate change. (nationalacademies.org/onpi/06072005.pdf; downloaded July 2012). 
Neumayer, E. 1999. Global warming: Discounting is not the issue, but substitutability is. Energy Policy, 27 (1):33-43.

Neumayer, E. 2007. A missed opportunity: The Stern review on climate change fails to tackle the issue of non-substitutable loss of natural capital'. Global Environmental Change 17:297-301.

Ng, W., and R. Mendelsohn, 2005. The impact of sea level rise on Singapore. Environ. Dev. Econ, 10:210-215.

Nicholls, R.J., and R.S.J. Tol. 2006. Impacts and responses to sea-level rise: A global analysis of the SRES scenarios over the 21st Century. Philos. Roy. Soc. A 364:1073-1095.

Niggli, U., A. Fließbach, P. Hepperly, and N. Scialabba. 2009. Low greenhouse gas agriculture: Mitigation and adaptation potential of sustainable farming systems. FAO. Rome.

Nordhaus, W.D. 1991. To slow or not to slow: The economics of the greenhouse effect. Econ. J. 101:920-937.

Nordhaus, W.D., 2007. The challenge of global warming: Economic models and environmental policy. http://nordhaus.econ.yale.edu/DICE2007.htm.

Nordhaus, W.D. 2008. A question of balance: Weighing the options on global warming policies. Yale University Press, New Haven.

Nordhaus, W.D., and J.G. Boyer.200o.Valuing the world: The economics of the greenhouse effect, MIT Press, Cambridge, MA.

Pearce, D.W. 1995. Valuing climate change. Chem. Ind. 12: 1024-1024.

Pearce, D.W., W.R. Cline, A.N. Achanta, S. Fankhauser, R.K. Pachauri, R.S. J. Tol, and P. Vellinga. 1996. The social costs of climate change: Greenhouse damage and the benefits of control. p. 179-224. In: J.P. Bruce, H. Lee, and E.F. Haites (eds.) Climate change 1995: Economic and social dimensions-Contribution of working group III to the Second Assessment Report of the IPCC. Cambridge University Press, Cambridge.

Pearce, F. 1995. Global row over value of human life. N. Sci. (August 19): 7

Penning de Vries, F.W.T., H. van Keulen, and R. Rabbinge. 1995. Natural resources and limits of food production in 2040. p. 65-87. In: Bouma, J., A. Kuyvenhoven, B.A.M. Bouman, J.C. Luyten and H.G. Zandstra (eds.) Eco-regional approaches for sustainable land use and food production. Kluwer Academic Publishers, The Netherlands.

Peters, G.P., G. Marland, C. Le Quere, T. Boden, J.G. Canadell, and M.R. Raupach. 2012. Rapid growth in $\mathrm{CO} 2$ emissions after the 2008-2009 global financial crisis. Nature Clim. Change 2:2-4.

Pimentel, D., and M. Pimentel. 1996. Food, energy and society. Niwot, CO, Colorado University Press.

Pimentel, D., P. Hepperly, J. Hanson, D. Douds, and R. Seidel. 2005. Environmental, energetic, and economic comparisons of organic and conventional farming systems. Bioscience 55:573-582.

Polimeni, J.M., Y.K. Mayumi, M. Giampietro, and B. Alcott. 2008. The Jevons paradox and the myth of resource efficiency improvements. Earthscan, London.

Quadrelli, R., and S. Peterson. 2007. The energy-climate challenge: Recent trends in $\mathrm{CO} 2$ emissions from fuel combustion. Energy Pol. 35:5938-5952.

Rahmstorf, S., and D. Coumou. 2011. Increase of extreme events in a warming world. Proc Natl Acad Sci USA. 108:17905-17909.

Raupach, M.R., G. Marland, P. Ciais, C. Le Quéré, J.G. Canadell, G. Klepper, and C.B. Field. 2007. Global and regional drivers of accelerating CO2 emissions. Proc. Natl. Acad. Sci. USA 104:10288-10293.

Reilly, J., F. Tubiello, B. Mccarl, D. Abler, R. Darwin, K. Fuglie, S. Hollinger, C. Izaurralde, S. Jagtap, J. Jones, L. Mearns, D. Ojima, E. Paul, K. Paustian, S. Riha, N. Rosenberg, and C. Rosenzweig. 2003. US agriculture and climate change: New results. Clim. Change 57:43-69.

Reilly J., S. Paltsev, B. Felzer, X. Wang, D. Kicklighter, J. Melillo, R. Prinn,M. Sarofim A. Sokolov, and C. Wang. 2007. Global economic effects of changes in crops, pasture, and forests due to changing climate, carbon dioxide, and ozone. Energy Pol. 35:5370-5383.

Rignot, E., I. Velicogna, M.R. van den Broeke, A. Monaghan, and J. Lenaerts. 2011. Acceleration of the contribution of the Greenland and Antarctic ice sheets to sea level rise. Geophys. Res. Lett. 38:L05503.

Roca, J., and V. Alcántara. 2001. Energy intensity, CO2 emissions and the environmental Kuznets curve: the Spanish case. Energy Policy 29:553-556.

Rosenzweig, C., and M.L. Parry. 1994. Potential impact of climate change on world food supply. Nature 367:133-138.

Schmalensee, R., T.M. Stoker, and R.A. Judson. 1998. World carbon dioxide emissions: 1950-2050. Rev. Econ. Stat. 80:15-27.

Seidl, A. 2000. Economic issues and the diet and the distribution of environmental impact. Ecol. Econ. 34:58.

Smith, P., D. Martino, Z. Cai, D. Gwary, H. Janzen, P. Kumar, B. McCarl, S. Ogle, F. O’Mara, C. Rice, B. Scholes, and O. Sirotenko. 2007. Agriculture. p. 497-540. In: B. Metz, O.R. Davidson, P.R. Bosch, R. 
Dave, and L.A. Meyer (eds.) Climate change (2007): Mitigation. Contribution of Working Group III to the Fourth Assessment Report of the Intergovernmental Panel on Climate Change. Cambridge University Press, Cambridge, U.K. and New York, NY.

Smith, T.M., R.W. Reynolds, T.C. Peterson, and J. Lawrimore. 2008. Improvements to NOAA's historical merged land-ocean surface temperature analysis (1880-2006). J. Clim. 21:2283-2296.

Solomon, S., D. Qin, M. Manning, Z. Chen, M. Marquis, K.B. Averyt, and M.M. Tignor. (eds.). 2007. Climate change 2007 - the physical science basis: Contribution of working group I to the fourth assessment report of the intergovernmental panel on climate change. Cambridge University Press, New York.

Spash, C.L. 2002. Greenhouse economics: Value and ethics. Routledge, London.

Spash, C.L. 2007. The economics of climate change impacts à la Stern: Novel and nuanced to rhetorically restricted? Ecol. Econ. 63:706-713.

Spash, C.L. 2010. The brave new world of carbon trading, N. Polit. Econ. 15(2):169-195.

Stanton, E. A., F. Ackerman, and S. Kartha. 2009. Inside the integrated assessment models: Four issues in climate economics. Clim. Dev. 1 (2):166-184.

Stehr, N., and H. von Storch. 2005. Introduction to papers on mitigation and adaptation strategies for climate change: protecting nature from society or protecting society from nature? Environmental Science \& Policy 8:537-540.

Stern, D.I. 2004. The rise and fall of the environmental Kuznets curve. World Dev 32:1419-1439.

Stern, D.I., and M.S. Common. 2001. Is there an environmental Kuznets curve for sulfur? J. Environm. Econ. Manag. 41:162-178.

Stern, N. 2006. The Stern review: The economics of climate change. HM Treasury, London.

Stern, N. 2007. The economics of climate change: The Stern review. Cambridge University Press, New York.

Stern, N. 2011. Statement by Nicholas Stern on Cancún agreement. Website of the Grantham Research Institute on Climate Change and the Environment, London School of Economics (www2.lse.ac.uk/GranthamInstitute/Media/Releases/2010/MR111210_cancun-agreement-stern.aspx).

Stillman, S. 2006. Health and nutrition in eastern Europe and the former Soviet Union during the decade of transition: A review of the literature. Econ. Hum. Biol. 4:104-146.

Sun, J.W., and T. Meristo. 1999. Measurement of dematerialization/materialization: A case analysis of energy saving and decarbonization in OECD countries, 1960-1995. Technological Forecasting and Social Change 60:275-294.

Suri, V., and D. Chapman. 1998. Economic growth, trade and energy: Implications for the environmental kuznets curve. Ecol. Econ. 25:195-208.

Tapia Granados, J.A., E.L. Ionides, and Ó. Carpintero. 2012. Climate change and the world economy: Shortrun determinants of atmospheric $\mathrm{CO}_{2}$. Environ. Sci. Pol. 21:50-62.

Taskin, F., and O. Zaim. 2000. Searching for a Kuznets curve in environmental efficiency using kernel estimation. Economics Letters 68:217-223.

Titus, J. G. 1992. The costs of climate change to the United States. p. 384-409. In: S. K. Majumdar, L. S. Kalkstein, B. M. Yarnal, E. W. Miller, and L. M. Rosenfeld (eds.) Global climate change: Implications, challenges and mitigation measures. Pennsylvania Academy of Science, Easton, PA.

Tol, R.S.J. 1995. The damage costs of climate change - Towards more comprehensive calculations. Environm. Resource Econ. 5:353-374.

Tol, R.S.J. 1997. The social cost controversy: A personal appraisal. p. 35-42. In: A. Sors, A. Liberatore, S. Funtowicz, J. C. Hourcade, and J. L. Fellous (eds.) Proceedings of the international symposium: Prospects for integrated environmental assessment: Lessons learnt from the case of climate change. European Commission DG12, Brussels.

Tol, R.S.J. 2002. Estimates of the damage costs of climate change, part 2: Dynamic estimates. Environm. Resources Econ. 21:135-160.

Tol, R.S.J., N. van der Grijp, A.A. Olsthoorn, and P.E. van der Werff. 2003. Adapting to climate: A case study on riverine flood risks in the Netherlands. Risk. Anal. 23:575-583.

Tol, R.S.J., S. Fankhauser, R.G. Richels, and J.B. Smith. 2000. How much damage will climate change do?, World Econ. 1 (4):179-206.

Tol, R.S.J., S.W. Pacala, and R.H. Socolow. 2009. Understanding long-term energy use and carbon dioxide emissions in the USA. J. Pol. Modeling 31:425-445. 
Tol, R.S.J., T.E. Downing, O.J. Kuik, and J.B. Smith. 2004. Distributional aspects of climate change impacts. Global Environm. Change 14:259-72.

Tol, R.S.J. 2008. The social cost of carbon: Trends, outliers and catastrophes. Economics-the Open-Access, Open-Assessment E-Journal, 2(25):1-24.

Tol, R.S.J. 2009. The economic effects of climate change. J. Econ. Perspectives 23(2):29-51.

Tol, R.S.J., S. Fankhauser, R.G. Richels, and J.B. Smith. 2000. How much damage will climate change do? World Econ. 1(4):179-206.

UNEP-UNCTAD Capacity-building Task Force on Trade, Environment and Development. 2008. Organic Agriculture and Food Security in Africa. United Nations. New York.

Velicogna, I. 2009. Increasing rates of ice mass loss from the Greenland and Antarctic ice sheets revealed by GRACE. Geophisic. Res. Letters 36:L19503.

Vidal, J. 2012. Bill Gates backs climate scientists lobbying for large-scale geoengineering - Other wealthy individuals have also funded reports on technologies to geoengineer the climate. The Guardian, February 5.

Wagner, M. 2008. The carbon Kuznets curve: A cloudy picture emitted by bad econometrics? Resource Energy Econ. 30:388-408.

Warren, R. 2011. The role of interactions in a world implementing change adaptation and mitigation solutions to climate. Phil. Trans. R. Soc. A 369 (1934):217-241.

Weiske, A., A. Vabitsch, J.E. Olesen, K. Schelde, J. Michel, R. Friedrich, and M. Kaltschmitt. 2006. Mitigation of greenhouse gas emission in European conventional and organic dairy farming. Agric. Ecosyst. Environm. 112:221-232.

Weyant, J.P., O. Davidson, H. Dowlatabadi, J.A. Edmonds, M.J. Grubb, E.A. Parson, R.G. Richels, J. Rotmans, P.R. Shukla, R.S.J. Tol, W. R. Cline, and S. Frankhauser. 1996. Integrated assessment on climate change: An overview and comparison of approaches and results. p. 367-396. In: J. P. Bruce, H. Lee, and E. F. Haites (eds.) Climate change 1995: Economic and social dimensions - Contributions of Working Group III to the Second Assessment Report of the IPCC. Cambridge University Press, Cambridge.

White, T. 2000. Diet and the distribution of environmental impact. Ecol. Econ. 34:145-153.

Willler, H., and L. Kilcher (eds.). 2009. The world of organic agriculture. Statistics and Emerging Trends 2009. IFOAM-FiBL-CH-Frick. Bonn.

Yohe, G.W., and M.E. Schlesinger. 1998. Sea-level change: The expected economic cost of protection or abandonment in the United States. Clim. Change, 38:447-472.

Zhang, Y., and W. Fan. 2003. History and civilization in China. Central Party Literature Press, Beijing. 
Table 1. Correlations $(r)$

in different periods be-

tween GDP growth and

the annual rate of growth

of $\mathrm{CO}_{2}$ emissions in the

United States

\begin{tabular}{cc}
\hline Period & $r$ \\
\hline $1800-1849$ & 0.37 \\
$1850-1899$ & 0.47 \\
$1900-1949$ & 0.62 \\
$1950-1999$ & 0.74 \\
& \\
$1800-1824$ & -0.07 \\
$1825-1849$ & 0.55 \\
$1850-1874$ & 0.69 \\
$1875-1899$ & 0.31 \\
$1900-1924$ & 0.54 \\
$1925-1949$ & 0.73 \\
$1950-1974$ & 0.74 \\
$1975-1999$ & 0.71 \\
\hline \multicolumn{2}{l}{ Computed by the authors from } \\
data in CDIAC (2009) and \\
Carter et al. (2006)
\end{tabular}

Table 2. Some estimates of welfare impacts of climate change, as equivalents of an income change measured as percent change of GDP

\begin{tabular}{|c|c|c|c|c|c|c|}
\hline \multirow[b]{2}{*}{ Study } & \multirow[b]{2}{*}{$\begin{array}{c}\text { Warming } \\
\text { in }{ }^{\circ} \mathrm{C}\end{array}$} & \multirow[b]{2}{*}{$\begin{array}{l}\text { Impact as } \\
\% \text { of GDP }\end{array}$} & \multicolumn{2}{|c|}{ Worst-off region } & \multicolumn{2}{|c|}{ Best-off region } \\
\hline & & & $\begin{array}{l}\text { \% of } \\
\text { GDP }\end{array}$ & Name & $\begin{array}{l}\text { \% of } \\
\text { GDP }\end{array}$ & Name \\
\hline Nordhaus 1994a & 3.0 & -1.3 & & & & \\
\hline Nordhaus 1994b & 3.0 & -4.8 & & & & \\
\hline Fankhauser 1995 & 2.5 & -1.4 & -4.7 & China & -0.7 & $\begin{array}{c}\text { Eastern } \\
\text { Europe \& the } \\
\text { former USSR }\end{array}$ \\
\hline Tol 1995 & 2.5 & -1.9 & -8.7 & Africa & -0.3 & $\begin{array}{c}\text { Eastern } \\
\text { Europe \& the } \\
\text { former USSR }\end{array}$ \\
\hline $\begin{array}{l}\text { Nordhaus \& Yang } \\
1996\end{array}$ & 2.5 & -1.7 & -2.1 & $\begin{array}{l}\text { Developing } \\
\text { countries }\end{array}$ & 0.9 & Former USSR \\
\hline $\begin{array}{l}\text { Nordhaus \& } \\
\text { Boyer } 2000\end{array}$ & 2.5 & -1.5 & -3.9 & Africa & 0.7 & Russia \\
\hline Tol 2002 & 1.0 & 2.3 & -4.1 & Africa & 3.7 & $\begin{array}{l}\text { Western } \\
\text { Europe }\end{array}$ \\
\hline Hope 2006 & 2.5 & 0.9 & -2.6 & $\begin{array}{l}\text { Asia (s/o } \\
\text { China) }\end{array}$ & 0.3 & $\begin{array}{c}\text { Eastern } \\
\text { Europe \& the } \\
\text { former USSR }\end{array}$ \\
\hline $\begin{array}{l}\text { Stern Review } \\
2006\end{array}$ & Increasing & 5 to 20 & & $\begin{array}{l}\text { Developing } \\
\text { countries }\end{array}$ & $\begin{array}{c}\text { Developed } \\
\text { countries }\end{array}$ & \\
\hline
\end{tabular}

Source: Adapted from Tol (2009). Estimation details in source reference. 
Table 3. Selected examples of mitigation technologies, policies and measures. Technologies projected to be commercialized before 2030 are shown in italics. For more details see text

\begin{tabular}{|c|c|c|c|c|}
\hline Sector & $\begin{array}{l}\text { Mitigation technologies and practices currently } \\
\text { commercially available }\end{array}$ & $\begin{array}{l}\text { Policies, measures and in- } \\
\text { struments shown to be envi- } \\
\text { ronmentally effective }\end{array}$ & $\begin{array}{l}\text { Price of ton } 0 \\
\text { / mitigation } \\
\text { tial }^{\text {a }}\end{array}$ & $\begin{array}{l}\mathrm{fO} 2 \\
\text { goten- }\end{array}$ \\
\hline \multirow[t]{3}{*}{$\begin{array}{l}\text { Energy } \\
\text { supply }\end{array}$} & \multirow{3}{*}{$\begin{array}{l}\text { Improved supply and distribution efficiency; } \\
\text { fuel switching from coal to gas; nuclear power; } \\
\text { renewable heat and power (hydropower, solar, } \\
\text { wind, geothermal and bioenergy); combined } \\
\text { heat and power; early applications of } \mathrm{CO}_{2} \text { cap- } \\
\text { ture and storage (CCS) (e.g. storage of removed } \\
\mathrm{CO}_{2} \text { from natural gas); CCS for gas, biomass } \\
\text { and coal-fired electricity generating facilities; } \\
\text { advanced nuclear power; advanced renewable } \\
\text { energy, including tidal and wave energy, con- } \\
\text { centrating solar, and solar photovoltaics. }\end{array}$} & $\begin{array}{l}\text { Reduction of fossil fuel sub- } \\
\text { sidies; taxes or carbon }\end{array}$ & $<\$ 20$ : & 1.9 \\
\hline & & charges on fossil fuels & $\$ 20$ to $\$ 50:$ & 1.4 \\
\hline & & $\begin{array}{l}\text { Feed-in tariffs for renewable } \\
\text { energy technologies; renew- } \\
\text { able energy obligations; pro- } \\
\text { ducer subsidies }\end{array}$ & \$50-100: & 0.35 \\
\hline \multirow[t]{7}{*}{ Transport } & \multirow{7}{*}{$\begin{array}{l}\text { More fuel-efficient vehicles; hybrid vehicles; } \\
\text { cleaner diesel vehicles; biofuels; modal shifts } \\
\text { from road transport to rail and public transport } \\
\text { systems; non-motorized transport (cycling, } \\
\text { walking); land-use and transport planning; sec- } \\
\text { ond generation biofuels; higher efficiency air- } \\
\text { craft; advanced electric and hybrid vehicles } \\
\text { with more powerful and reliable batteries. }\end{array}$} & $\begin{array}{l}\text { Mandatory fuel economy; } \\
\text { biofuel blending and } \mathrm{CO} 2\end{array}$ & $<\$ 20:$ & 1.75 \\
\hline & & $\begin{array}{l}\text { standards for road transport. } \\
\text { Taxes on vehicle purchase, }\end{array}$ & $\$ 20$ to $\$ 50:$ & 0.15 \\
\hline & & $\begin{array}{l}\text { registration, use and motor } \\
\text { fuels; road and parking pric- } \\
\text { ing. }\end{array}$ & 50 to $100:$ & 0.15 \\
\hline & & Influence mobility needs & & \\
\hline & & & & \\
\hline & & investment in attractive pub- & & \\
\hline & & $\begin{array}{l}\text { lic transport facilities and } \\
\text { non-motorized forms of } \\
\text { transport }\end{array}$ & & \\
\hline \multirow[t]{4}{*}{ Buildings } & \multirow{4}{*}{$\begin{array}{l}\text { Efficient lighting and daylighting; more efficient } \\
\text { electrical appliances and heating and cooling } \\
\text { devices; improved cook stoves, improved insula- } \\
\text { tion; passive and active solar design for heating } \\
\text { and cooling; alternative refrigeration fluids, } \\
\text { recovery and recycling of fluorinated gases; in- } \\
\text { tegrated design of commercial buildings in- } \\
\text { cluding technologies, such as intelligent meters } \\
\text { that provide feedback and control; solar photo- } \\
\text { voltaics integrated in buildings }\end{array}$} & $\begin{array}{l}\text { Appliance standards and } \\
\text { labeling }\end{array}$ & $<\$ 20:$ & $5 \cdot 5^{\mathrm{b}}$ \\
\hline & & $\begin{array}{l}\text { Building codes and certifica- } \\
\text { tion }\end{array}$ & $\$ 20$ to 100: & 0.6 \\
\hline & & $\begin{array}{l}\text { Demand-side management } \\
\text { programs }\end{array}$ & & \\
\hline & & $\begin{array}{l}\text { Public sector leadership pro- } \\
\text { grams, including procure- } \\
\text { ment incentives for energy } \\
\text { service companies }\end{array}$ & & \\
\hline \multirow[t]{5}{*}{ Industry } & \multirow{5}{*}{$\begin{array}{l}\text { More efficient end-use electrical equipment; } \\
\text { heat and power recovery; material recycling and } \\
\text { substitution; control of non-CO2 gas emissions; } \\
\text { and a wide array of process-specific technolo- } \\
\text { gies; advanced energy efficiency; CCS for ce- } \\
\text { ment, ammonia, and iron manufacture; inert } \\
\text { electrodes for aluminum manufacture }\end{array}$} & \multirow{5}{*}{$\begin{array}{l}\text { Provision of benchmark in- } \\
\text { formation; performance } \\
\text { standards; subsidies; tax } \\
\text { credits } \\
\text { Tradable permits } \\
\text { Voluntary agreements }\end{array}$} & $<\$ 20$ : & 1.1 \\
\hline & & & $\$ 20$ to $\$ 50:$ & 2.4 \\
\hline & & & $\$ 50$ to 100: & 0.55 \\
\hline & & & & \\
\hline & & & & \\
\hline \multirow[t]{3}{*}{$\begin{array}{l}\text { Agricul- } \\
\text { ture }\end{array}$} & \multirow{3}{*}{$\begin{array}{l}\text { Improved crop and grazing land management to } \\
\text { increase soil carbon storage; restoration of cul- } \\
\text { tivated peaty soils and degraded lands; im- } \\
\text { proved rice cultivation techniques and livestock } \\
\text { and manure management to reduce } \mathrm{CH}_{4} \text { emis- } \\
\text { sions; improved nitrogen fertilizer application } \\
\text { techniques to reduce N2O emissions; dedicated } \\
\text { energy crops to replace fossil fuel use; improved } \\
\text { energy efficiency; improvements of crop yields }\end{array}$} & \multirow{3}{*}{$\begin{array}{l}\text { Financial incentives and } \\
\text { regulations for improved } \\
\text { land management; maintain- } \\
\text { ing soil carbon content; effi- } \\
\text { cient use of fertilizers and } \\
\text { irrigation }\end{array}$} & $<\$ 20:$ & 1.6 \\
\hline & & & $\$ 20$ to $\$ 50:$ & 1.1 \\
\hline & & & $\$ 50$ to 100: & 1.7 \\
\hline
\end{tabular}


Fores- Afforestation; reforestation; forest managetry/forests ment; reduced deforestation; harvested wood product management; use of forestry products for bioenergy to replace fossil fuel use; tree species improvement to increase biomass productivity and carbon sequestration; improved remote sensing technologies for analysis of vegetation/soil carbon sequestration potential and mapping land-use change.

Waste Landfill $\mathrm{CH}_{4}$ recovery; waste incineration with energy recovery; composting of organic waste; controlled wastewater treatment; recycling and waste minimization; biocovers and biofilters to optimize $\mathrm{CH}_{4}$ oxidation
Financial incentives (national and international) to increase forest area, to reduce deforestation and to maintain and manage forests; land-use regulation and enforcement.

Financial incentives for improved waste and wastewater management Renewable energy incentives or obligations

Waste management regulations
< \$20: $\quad 1.25$

$\$ 20$ to $\$ 50: \quad 0.90$

\$50 to 100: 0.65

<\$20: $\quad 0.58$

$\$ 20$ to $\$ 50: 0.10$

\$50 to 100: 0.04

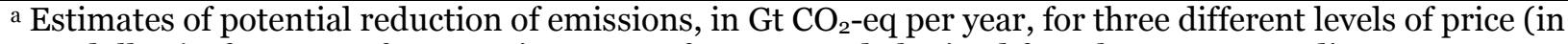
U.S. dollars) of one ton of $\mathrm{CO}_{2}$. Estimates are for 2030 and obtained from bottom-up studies.

b Most of this 5.5 would be the result of improvements at no cost that therefore would produce some net monetary benefits.

Source: Adapted from IPCC (2007, p. 60) and Baker et al. (2007) 
Figure 1. Atmospheric concentrations of $\mathrm{CO}_{2}$ (monthly average) as measured in air samples collected at Mauna Loa, Hawaii (Keeling curve) from February 1958 to February 2012. Units are parts per million by volume. Preindustrial concentrations, estimated at levels between 200 and 300 ppm, would be far out of the graph

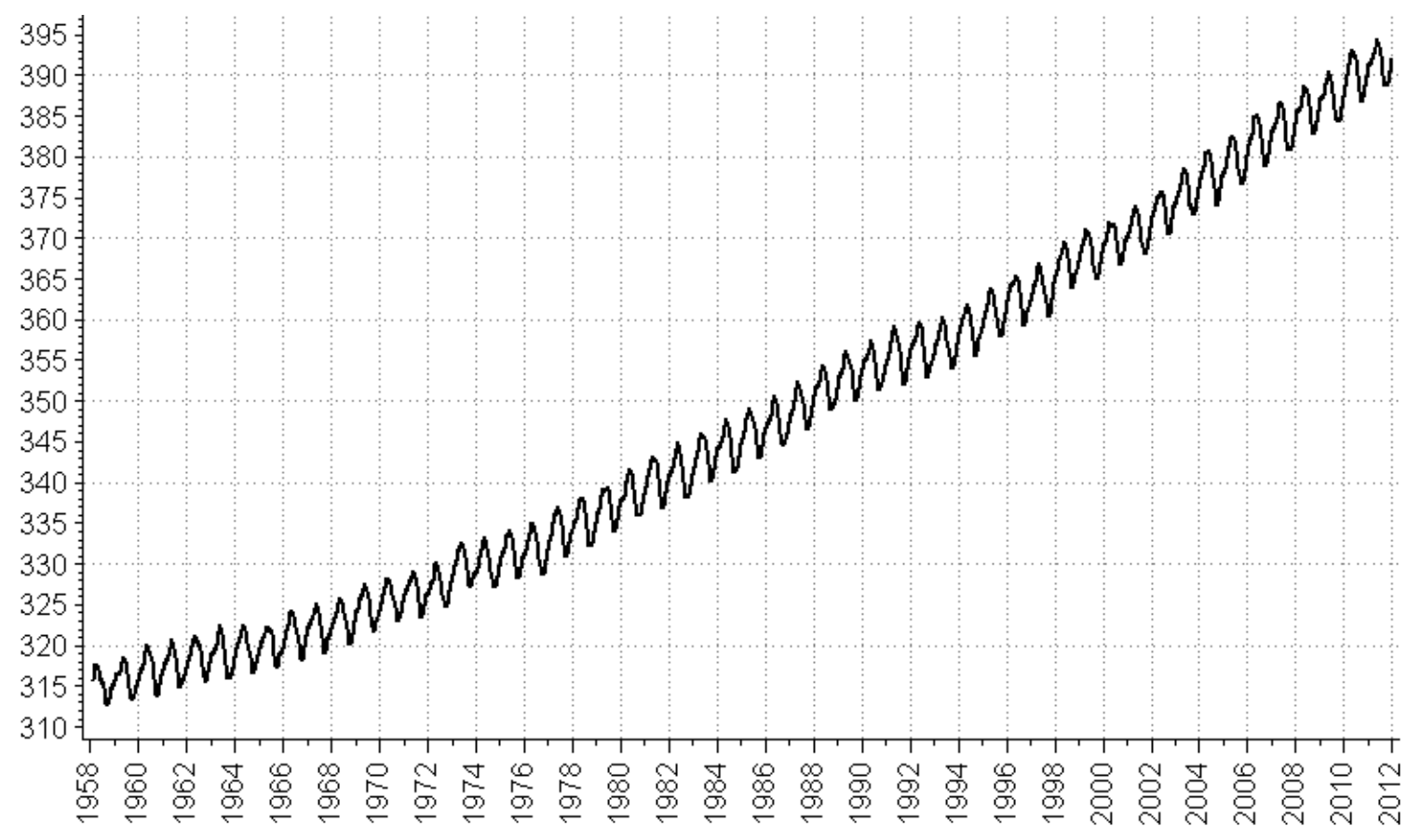


Figure 2. Per capita annual emissions of $\mathrm{CO}_{2}$ plotted versus GDP per capita, 1960-2006 (except for USA as indicated), G-20 coun-
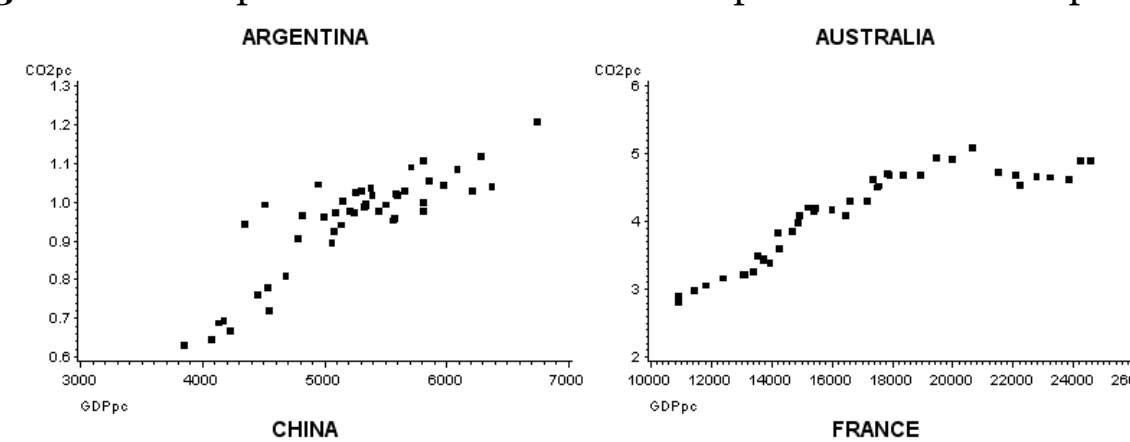

BRAZIL

CANADA
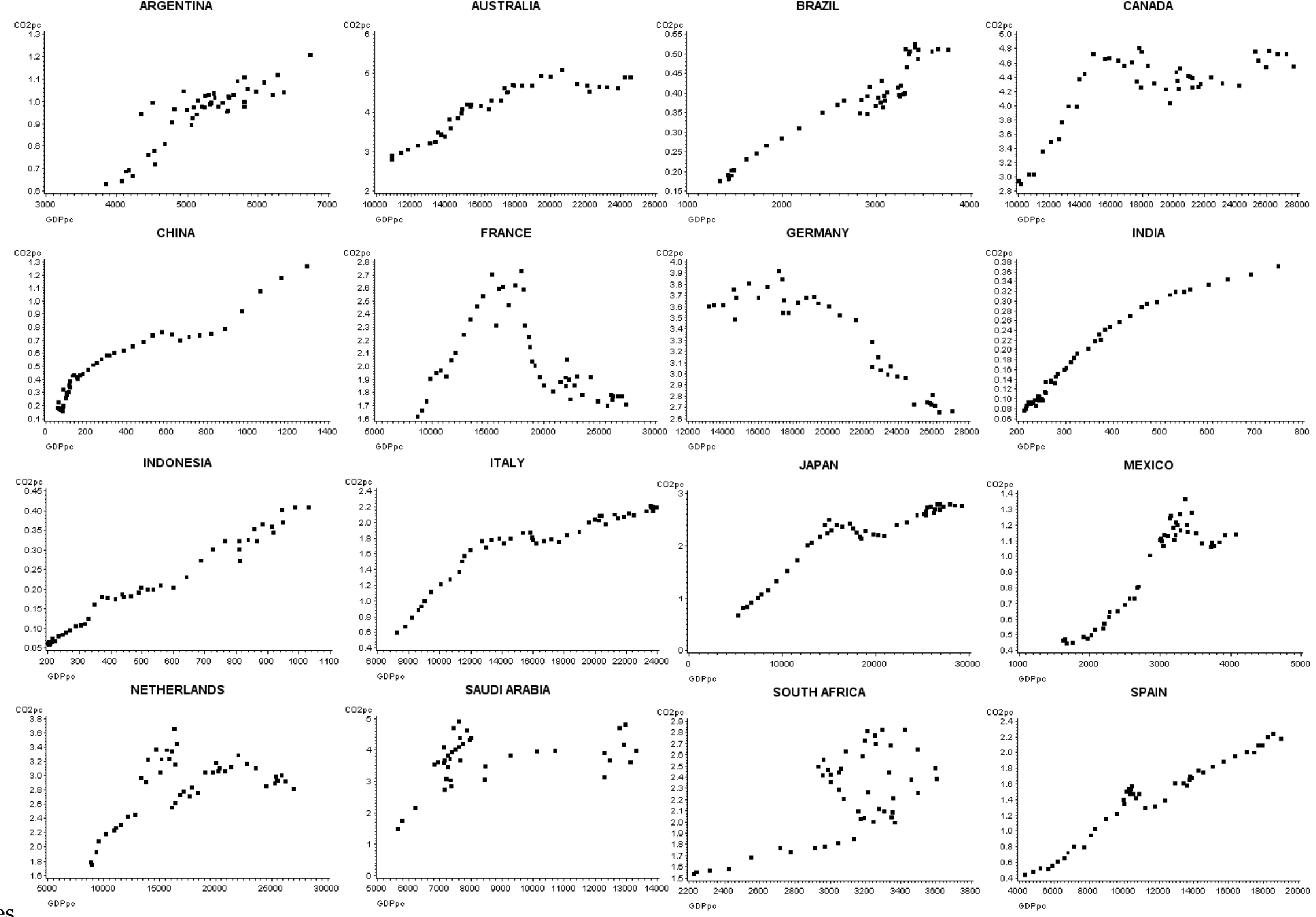

tries

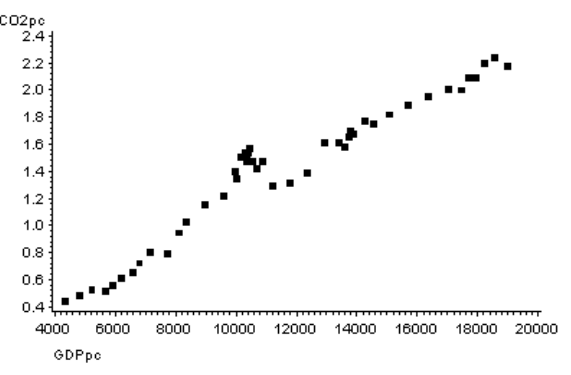


Fig 2 (cont.). Per capita annual emissions of $\mathrm{CO}_{2}$ plotted versus GDP per capita, 1960-2006 (except for USA as indicated)
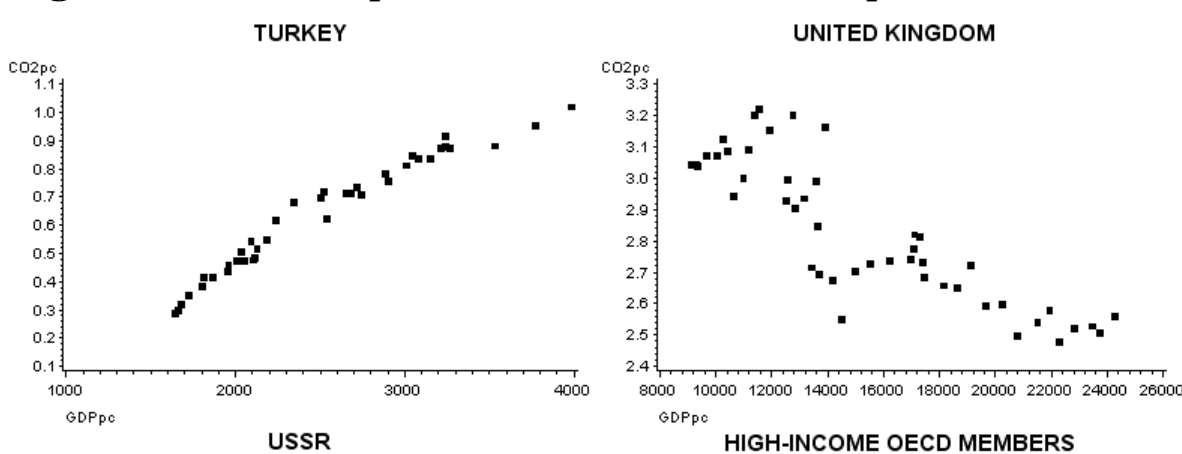

USA, data HistoStats, 1950-2000

USA, data HistoStat, 1870-2000
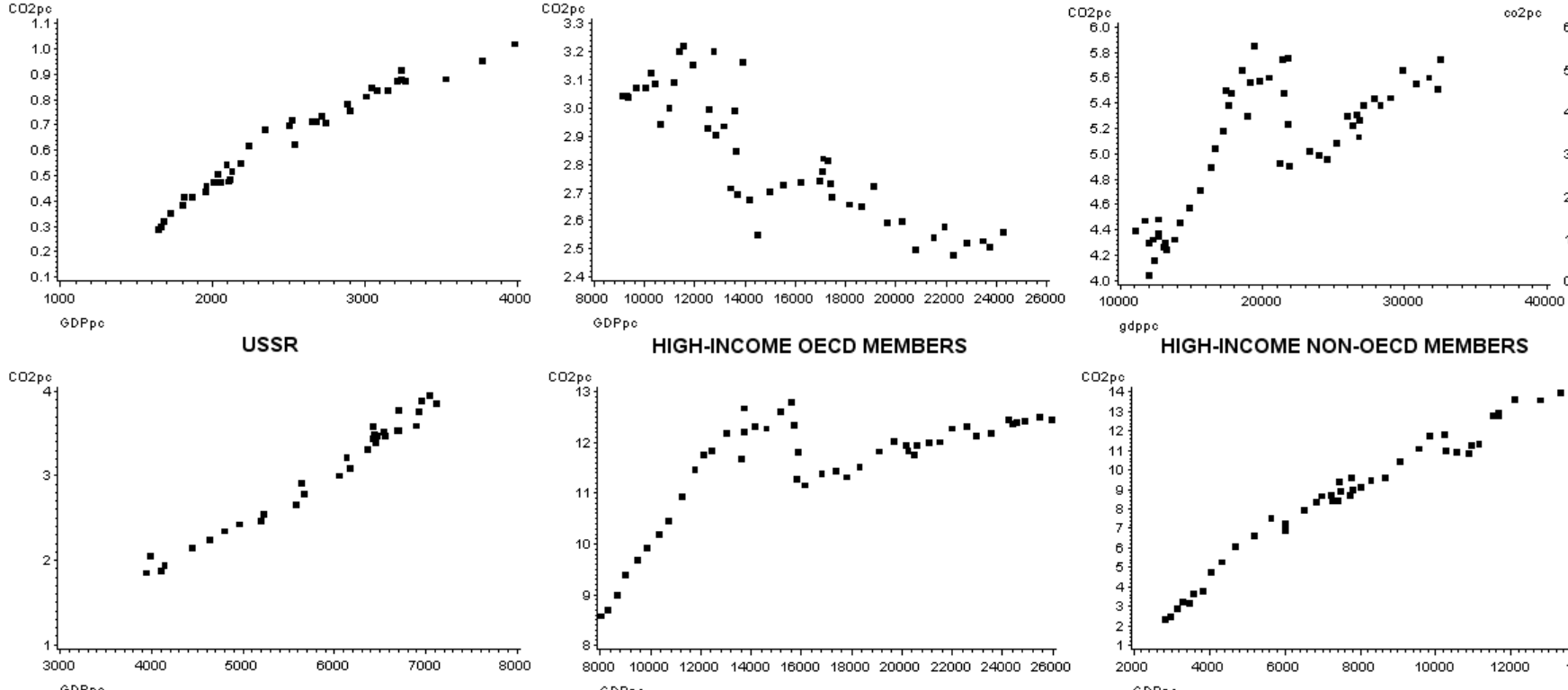

HIGH-INCOME NON-OECD MEMBERS
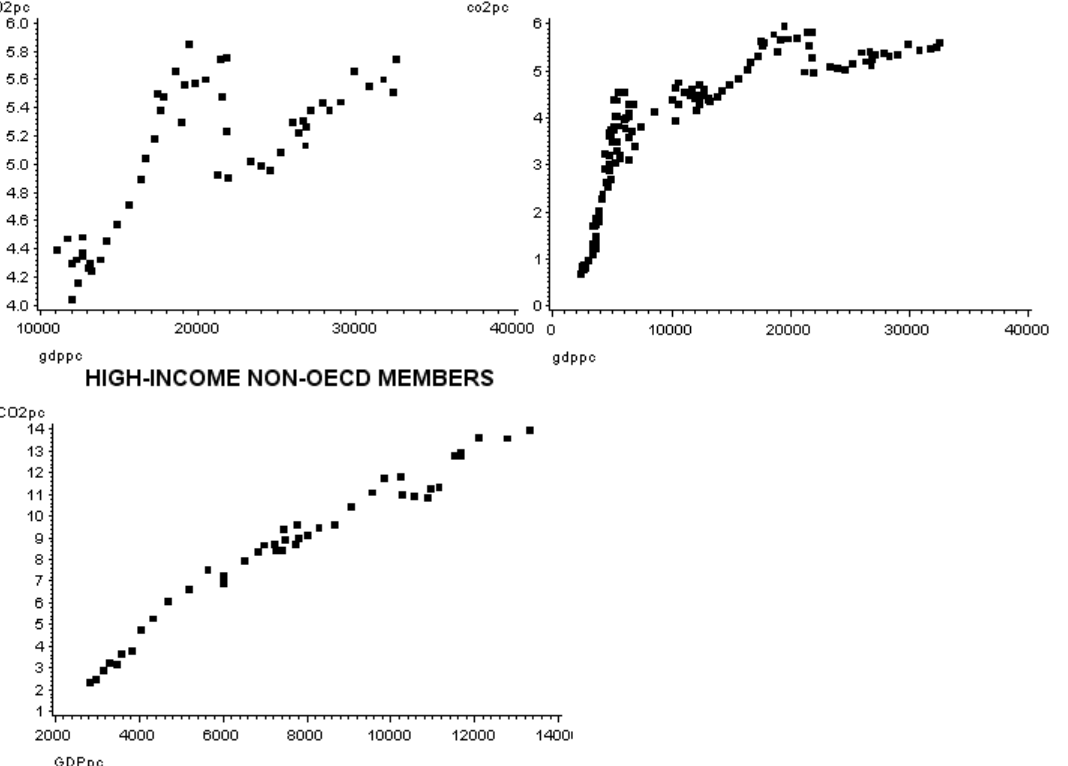

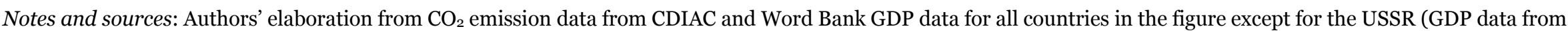

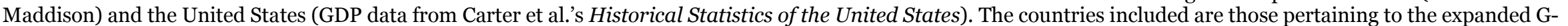

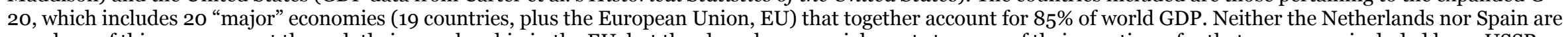
members of this group except through their membership in the EU, but they have been special guests to some of their meetings; for that reason are included here. USSR data are for the years before the USSR disappeared, i. e., until 1991. 
Figure 3. Annual growth of world GDP (gray line, trillions of 2000 US dollars), and annual change of estimated $\mathrm{CO}_{2}$ emissions (millions of Kt, red dots)

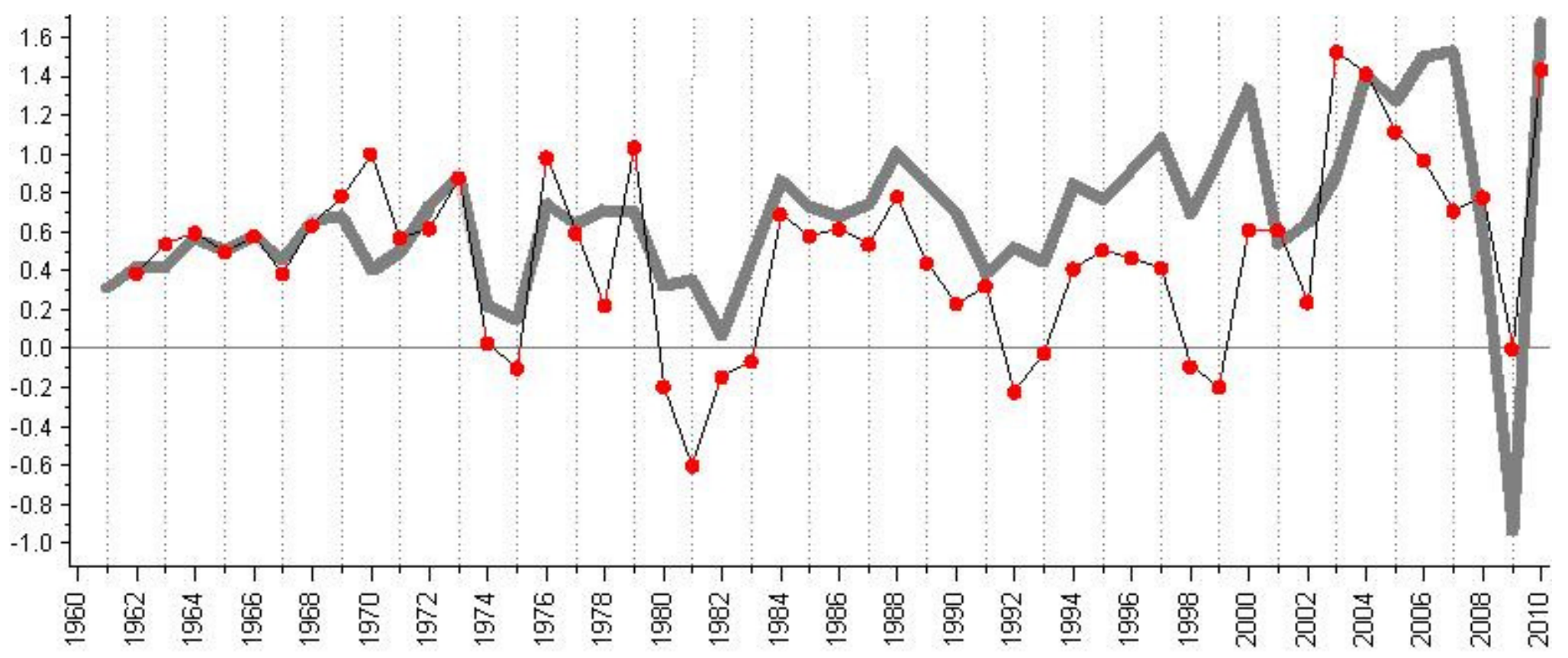

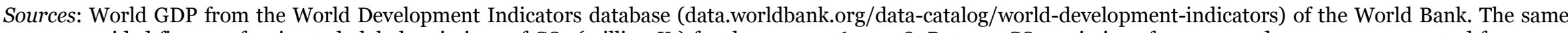

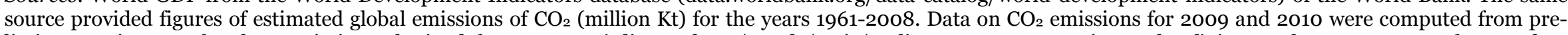

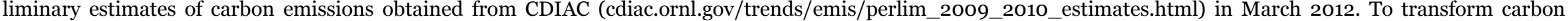
emissions into $\mathrm{CO}_{2}$ emissions the factor 3.67 was used. 